\title{
PET Diagnostic Molecules Utilizing Multimeric Cyclic RGD Peptide Analogs for Imaging Integrin $\alpha_{v} \beta_{3}$ Receptors
}

\author{
Christos Liolios $1,2, *(1)$, Christos Sachpekidis ${ }^{3}$, Antonios Kolocouris ${ }^{2}$, Antonia Dimitrakopoulou-Strauss ${ }^{3}$ \\ and Penelope Bouziotis $1, *(\mathbb{D}$ \\ 1 Radiochemical Studies Laboratory, Institute of Nuclear \& Radiological Sciences \& Technology, \\ Energy \& Safety, National Centre for Scientific Research "Demokritos", Ag. Paraskevi Attikis, \\ 15310 Athens, Greece \\ 2 Laboratory of Medicinal Chemistry, Department of Pharmacy, Section of Pharmaceutical Chemistry, \\ National and Kapodistrian University of Athens, Panepistimioupolis-Zografou, 15771 Athens, Greece; \\ ankol@pharm.uoa.gr \\ 3 Clinical Cooperation Unit Nuclear Medicine, German Cancer Research Center (DKFZ), \\ 69120 Heidelberg, Germany; c.sachpekidis@dkfz-heidelberg.de (C.S.); \\ a.dimitrakopoulou-strauss@dkfz-heidelberg.de (A.D.-S.) \\ * Correspondence: liolios.xr@gmail.com (C.L.); bouzioti@rrp.demokritos.gr (P.B.)
}

\section{check for} updates

Citation: Liolios, C.; Sachpekidis, C.; Kolocouris, A.; DimitrakopoulouStrauss, A.; Bouziotis, P. PET Diagnostic Molecules Utilizing Multimeric Cyclic RGD Peptide Analogs for Imaging Integrin $\alpha_{\mathrm{v}} \beta_{3}$ Receptors. Molecules 2021, 26, 1792 https: / / doi.org/10.3390/ molecules26061792

Academic Editors: Anne Roivainen and Xiang-Guo Li

Received: 11 February 2021

Accepted: 17 March 2021

Published: 22 March 2021

Publisher's Note: MDPI stays neutral with regard to jurisdictional claims in published maps and institutional affiliations.

Copyright: (c) 2021 by the authors. Licensee MDPI, Basel, Switzerland. This article is an open access article distributed under the terms and conditions of the Creative Commons Attribution (CC BY) license (https:/ / creativecommons.org/licenses/by/ $4.0 /)$.

\begin{abstract}
Multimeric ligands consisting of multiple pharmacophores connected to a single backbone have been widely investigated for diagnostic and therapeutic applications. In this review, we summarize recent developments regarding multimeric radioligands targeting integrin $\alpha_{\mathrm{V}} \beta_{3}$ receptors on cancer cells for molecular imaging and diagnostic applications using positron emission tomography (PET). Integrin $\alpha_{\mathrm{v}} \beta_{3}$ receptors are glycoproteins expressed on the cell surface, which have a significant role in tumor angiogenesis. They act as receptors for several extracellular matrix proteins exposing the tripeptide sequence arginine-glycine-aspartic (RGD). Cyclic RDG peptidic ligands c(RGD) have been developed for integrin $\alpha_{v} \beta_{3}$ tumor-targeting positron emission tomography (PET) diagnosis. Several c(RGD) pharmacophores, connected with the linker and conjugated to a chelator or precursor for radiolabeling with different PET radionuclides $\left({ }^{18} \mathrm{~F},{ }^{64} \mathrm{Cu}\right.$, and $\left.{ }^{68} \mathrm{Ga}\right)$, have resulted in multimeric ligands superior to c(RGD) monomers. The binding avidity, pharmacodynamic, and PET imaging properties of these multimeric c(RGD) radioligands, in relation to their structural characteristics are analyzed and discussed. Furthermore, specific examples from preclinical studies and clinical investigations are included.
\end{abstract}

Keywords: PET imaging; multimeric radioligands; integrin $\alpha_{\mathrm{v}} \beta_{3}$; cyclic RGD

\section{Introduction \\ 1.1. Multimeric Radioligands}

The idea of multimeric radioligand, which consists of multiple structural motifs connected to a single backbone, started from the need to achieve higher binding avidity through cooperative multivalent interactions. In a way, this mimics the behavior of antibodies, which have multiple individual weak interactions with the target. These multiple weak interactions combine in a cooperative way and increase binding avidity [1,2]. Several binding modes have been proposed as an explanation for this cumulative effect, such as the simultaneous binding of the ligand to multiple receptors on the cell surface (Figure 1a), or the improved statistical effect, where the ligand binds to one receptor, but the ligand's apparent local concentration is increased (Figure 1b) [1].

Multimeric radioligands resemble a typical radioligand by retaining some of its structural features - e.g., a chelator group for radiometals - and differ from it, as they include multiple pharmacophores. Radioligands targeting specific receptors on tumor cell surfaces consist of a receptor binding section (pharmacophore or ligand), and a radiolabeled domain. The latter is either a radiometal chelator, which coordinates with a radiometal, or a 
suitable group for radio-halogenation, which is often connected with the pharmacophore through a linker (spacer) group. Linker groups are used (Figure 1): (1) to increase the distance between the ligand and the chelator group and thus, minimize the interference of the radiolabeled domain with the binding pocket of the ligand in the receptor; (2) to enhance the interactions between the ligand and its binding pocket; (3) to enable the addition of a second or of multiple binding pharmacophore groups leading to multimeric ligands; (4) to increase the distance between the multiple pharmacophores in order to enable simultaneous binding on more than one receptors (Figure 1a); (5) to change the pharmacokinetic properties of the radioligand, altering its hydrophobicity and eventually increase its apparent local concentration when it reaches the receptor's binding area [3-5].

a)

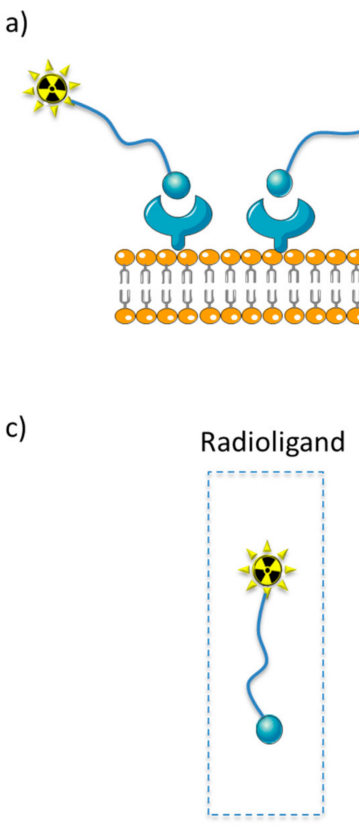

b)

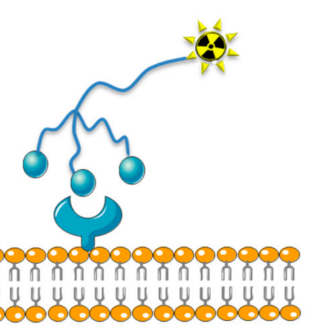

Figure 1. Binding models for multimers on the cell surface: (a) The binding of a radioligand to a cell surface receptors and the multimeric approach resulting in simultaneous binding of two pharmacophores connected via a long linker with two receptors, (b) improved binding efficiency of a ligand, due to the increased apparent local concentration of the pharmacophore (statistical effect) in the micro-environment of the receptor; (c) basic principles for the design of monomeric and multimeric radioligands (where $n=$ number of pharmacophores).

The linker properties are very important since they influence the orientation of the ligand, when it approaches the extracellular receptors binding domain, enabling or preventing simultaneous multi-receptor binding of the multimers [6]. Long, flexible linkers increase the distance between the binding domains, permitting simultaneous binding of the ligand to multiple receptors, while rigid linkers have less entropy penalty from binding [1].

For multimeric radioligands, a wide spectrum of pharmacophores has been used like small molecules, peptides, or fractions of antibodies [1,6-9]. A limited number $(n=2-8)$ of pharmacophores e.g., $\mathrm{c}(\mathrm{RGD})_{\mathrm{n}}$ has been covalently connected using low molecular weight linkers e.g., polyethylene glycols (PEGs), while higher numbers of pharmacophores have been tethered on the surface of large molecules, such as liposomes or nanoparticles. The nanoparticle approach is not examined in this review.

\subsection{Multimerization of Cyclic RGD Peptides}

Angiogenesis is a fundamental process required for tumor survival, proliferation, and progression [10]. Among the factors regulating angiogenesis are the proteins known as integrins $[11,12]$. Overexpression of integrins on cancer cells potentiates metastasis by facilitating their invasion and movement across the blood vessels [13]. In particular, 
integrins $\alpha_{\mathrm{v}} \beta_{3}$ are considered an ideal target for the development of radioligands, since they are overexpressed on tumor vasculature due to angiogenesis, and on the cell membrane in various tumors, i.e., ovarian cancer [14], neuroblastoma [15], breast cancer [16-18] and melanoma [19]. Integrins $\alpha_{v} \beta_{3}$ are transmembrane receptors for several extracellular matrix proteins exposing the tripeptide sequence arginine-glycine-aspartic (RGD). The tripeptide RGD amino acid sequence specifically binds to the integrin $\alpha_{\mathrm{v}} \beta_{3}$ receptor and this has also provided the platform for the development of cyclic RGD, c(RGD), radioligands [20].

The incorporation of the RGD sequence into a cyclic pentapeptide: cyclo-(Arg-GlyAsp-D-Phe-Val), $c($ RGDfV), has been found to increase binding affinity and selectivity for integrin $\alpha_{V} \beta_{3}$ receptor over glycoprotein IIb/IIIa (also known as integrin $\alpha_{I I b} \beta_{3}$ ) [20]. After extensive structure-activity evaluations, it was concluded that the 5th amino acid has no significant impact on integrin $\alpha_{\mathrm{v}} \beta_{3}$ binding affinity. Thus, the valine residue in c(RGDfV) was replaced by lysine or glutamic acid to afford cyclo-(Arg-Gly-Asp-D-Phe-Lys) or cyclo-(Arg-Gly-Asp-D-Tyr-Glu) c(RGDfK) and c(RGDfE), respectively, without changing the integrin $\alpha_{\mathrm{v}} \beta_{3}$ binding affinity. The replacement of the 5th amino acid was crucial since it enabled further modification (e.g., conjugation to a chelator group) via the formation of peptide bonds with the side group of K or E, respectively [20].

Multimeric $c(R G D)$ radioligands consist of several binding domains: $c($ RGDfK), $c($ RGDfE), $c($ RGDyK), tethered together via some sort of backbone e.g., c(RGDfK)-X$c($ RGDfK) $(X=$ linker). In low molecular weight multimers, $X$ is composed of amino acids: Glu (E), Lys (K), enabling the installation of the radiolabeled section with a chelator group and multiple binding domains. Sometimes a polyethylene glycol unit $\mathrm{PEG}_{\mathrm{n}}(n=$ number of polyethylene glycol units) is also introduced to increase the distance between the pharmacophores and the radiolabeled domain [20,21]. For example, if $X=G l u(E)$ multimerization can be accomplished by connecting its alpha $-\mathrm{NH}_{2}$ with a chelator while conjugating with peptide bonds the alpha $-\mathrm{COOH}$ and the side chain $-\mathrm{CH}_{2} \mathrm{COOH}$, with the 5th amino acid (K) of two c(RGDfK) pharmacophores. The linkage structure plays a critical role in the pharmacodynamic properties of the $\mathrm{c}(\mathrm{RGDfK})_{\mathrm{n}}$ multimeric ligands e.g., attaching a long PEG chain to the amino acid linker has proved advantageous for enhancing avidity and tumor uptake. The synthesis of such molecules is usually accomplished using orthogonal, sequential solid-phase peptide synthesis (spps), liquid phase peptide synthesis [20,22], or conjugation of the different parts using copper-catalyzed azide-alkyne cycloaddition (CuAAC) [23].

Based on this framework, a variety of radiolabeled cRGD peptides has been developed for non-invasive imaging of integrin $\alpha_{\mathrm{v}} \beta_{3}$ expression with PET, e.g., $\left[{ }^{18} \mathrm{~F}\right] \mathrm{FP}-\mathrm{PRGD} \mathrm{P}_{2}$ or $\left[{ }^{18} \mathrm{~F}\right] \mathrm{FP}-\mathrm{PEG}_{3}-\mathrm{E}[\mathrm{c}(\mathrm{RGDyK})]_{2} \mathrm{8}^{8},\left[{ }^{18} \mathrm{~F}\right]$ Alfatide I or $\left[{ }^{18} \mathrm{~F}\right]$ AlF-NOTA-PEG 3 -E[c(RGDyK) $]_{2}$ 10, $\left[{ }^{18} \mathrm{~F}\right]$ Alfatide II or $\left[{ }^{18} \mathrm{~F}\right]$ AlF-NOTA-E[PEG $4^{-c}($ RGDfK $\left.)\right]_{2}$ 14; $\left[{ }^{68} \mathrm{Ga}\right]$ Ga-NOTA-PEG $4^{-}$ $\mathrm{E}[\mathrm{c}(\mathrm{RGDfK})]_{2}$ 12, $\left[{ }^{68} \mathrm{Ga}\right] \mathrm{Ga}-\mathrm{NOTA}-\mathrm{E}\left[\mathrm{PEG}_{4}-\mathrm{c}(\mathrm{RGDfK})\right]_{2}$, or $\left[{ }^{68} \mathrm{Ga}\right] \mathrm{Ga}-\mathrm{NOTA}-\mathrm{PRGD}_{2} 15$ and $\left.\left[{ }^{64} \mathrm{Cu}\right] \mathrm{Cu}-\mathrm{NOTA}\right]-\mathrm{PEG}_{4}-\mathrm{cRGD}{ }_{2}$ or $\left[{ }^{64} \mathrm{Cu}\right] \mathrm{Cu}-\mathrm{DOTA}-\mathrm{E}\left(\mathrm{E}\left\{\mathrm{E}[\mathrm{c}(\mathrm{RGDyK})]_{2}\right\}_{2}\right)_{2} 28$ (where NOTA $=1,4,7$-triazacyclononane-1,4,7-triacetic acid, PEG $_{3}=12$-amino-4,7,10trioxadodecanoic acid, $\mathrm{PEG}_{4}=15$-amino-4,7,10,13-tetraoxapentadecanoic acid) [24-26]. The various pharmacophores: $c($ RGDfK), c(RGDyK), c(RGDfE), are all confusingly abbreviated in the literature as $\operatorname{RGD}_{\mathrm{v}}(\mathrm{v}=$ number of pharmacophores), and with the addition of a PEG linker as PRGD ${ }_{v}$ independently of the PEG length. Among the multimers hitherto evaluated in preclinical studies, the dimeric structures are the most successful. The majority of these dimers has already advanced in clinical oncological studies $(8,10,12,14,15)$ while some of them have also been studied for other pathological conditions apart from cancer e.g., $\left[{ }^{18} \mathrm{~F}\right] \mathrm{FP}-\mathrm{PRGD}_{2}$ or $\left[{ }^{18} \mathrm{~F}\right] \mathrm{FP}-\mathrm{PEG}_{3}-\mathrm{E}[\mathrm{c}(\mathrm{RGDfK})]_{2} 8$ for the prediction of fibrosis in non-alcoholic steatohepatitis [27]. Several groups prepared c(RGD) tetramers [28,29] and octamers [30] based on the observation that pharmacophore multiplicity may increase the integrin $\alpha_{v} \beta_{3}$ binding avidity and ligand cell-internalization [30]. However, none of these multimers has advanced to clinical studies. The goal of this review is to summarize recent developments of $c(R G D)_{n}$ multimeric radioligands, which target the 
integrin $\alpha_{v} \beta_{3}$ receptors, for cancer diagnosis using positron emission tomography (PET) molecular imaging.

\section{Preclinical Studies of Multimeric Cyclic RGD Peptides}

\section{1. ${ }^{18} \mathrm{~F}$ Labeled Cyclic RGD Multimers}

The majority of PET imaging preclinical and clinical studies refer to ${ }^{18} \mathrm{~F}$ labeled $\mathrm{c}(\mathrm{RGD})_{\mathrm{n}}$ multimers, while following them are the ${ }^{68} \mathrm{Ga}$ and ${ }^{64} \mathrm{Cu}$ labeled ones. ${ }^{18} \mathrm{~F}$ is a PET radioisotope combining favorable physical and chemical characteristics (half-life $=109 \mathrm{~min}$, $\beta^{+} 96.7 \%, 0.64 \mathrm{MeV}$ ), which can be easily produced as aqueous fluoride by means of proton irradiation of ${ }^{18} \mathrm{O}$-enriched water with a biomedical cyclotron [31]. ${ }^{18} \mathrm{~F}$-radiolabeling is achieved using reactions of nucleophilic substitution on suitable precursors, which carry appropriate leaving groups e.g., halides, sulfonates, and ammonium cations, or aromatic rings with activating residues like electron-withdrawing groups in appropriate positions [32].

Poethko et al. in one of the first studies on ${ }^{18} \mathrm{~F}$-multimeric $\mathrm{c}(\mathrm{RGD})$ radioligands used 4- $\left[{ }^{18} \mathrm{~F}\right]$ Fluorobenzaldehyde, which was conjugated to $\mathrm{H}_{2} \mathrm{~N}-\mathrm{O}-\mathrm{CH}_{2}-\mathrm{CO}-\mathrm{NH}$-functionalized peptides forming an oxime $N-\left(4-\left[{ }^{18} \mathrm{~F}\right]\right.$ Fluorobenzylidene $)$ oxime $\left(\left[{ }^{18} \mathrm{~F}\right] \mathrm{FBOA}\right)$. The pharmacophores were linked to $\left[{ }^{18} \mathrm{~F}\right] \mathrm{FBOA}$ through 2,3-diaminopropionic acid (Dpr) connected to a Lys linker. The alpha and side-chain -COOH groups of Lys were conjugated to the Glu of each pentapeptide $c$ (RGDfE) pharmacophore using a $\mathrm{PEG}_{6}$ group $\left(\mathrm{H}_{2} \mathrm{~N}-\mathrm{PEG}_{6}-\mathrm{CH}_{2} \mathrm{COOH}\right)$. The $\left[{ }^{18} \mathrm{~F}\right]$ FBOA-Dpr-HEG-c(RGDfE) monomer $\mathbf{1}$ was compare with the dimeric $\left[{ }^{18} \mathrm{~F}\right] \mathrm{FBOA}-$ Dpr-K(HEG-c(RGDfE) $)_{2}$ 2, and tetrameric $\left[{ }^{18} \mathrm{~F}\right] \mathrm{FBOA}-\mathrm{Dpr}-\mathrm{K}\left\{\mathrm{K}\left[\mathrm{HEG}-(\mathrm{c}(\mathrm{RGDfE})]_{2}\right\}_{2} 3\right.$ structure (Figure 2) [22,33]. Biodistribution studies for c(RGDfE) derivatives 1-3 were performed in mice bearing human melanoma M21 xenographs, overexpressing $\alpha_{v} \beta_{3}$ integrin and M21-L, weakly expressing $\alpha_{\mathrm{V}} \beta_{3}$ integrin (negative control). Tumor uptake was higher for the dimeric structure 2 (60 min post-injection [p.i.]: $2.48 \pm 0.15$ percent of injected dose per gram [\% ID/g]; $120 \mathrm{~min}$ p.i.: $1.63 \pm 0.13 \% \mathrm{ID} / \mathrm{g}$ ) compared to the monomer 1 (60 $\mathrm{min}$ p.i.: $1.56 \pm 0.15 \% \mathrm{ID} / \mathrm{g} ; 120 \mathrm{~min}: 1.49 \pm 0.10 \% \mathrm{ID} / \mathrm{g}$ ). Tumor uptake (M21 tumor) was higher by a factor of 5- 6 than the negative control (M21-L), and specific, as it was proved by blocking studies. In another complementary study between ligands 1-3, the tetrameric ligand 3 showed similar tumor uptake with 2 (120 min p.i.: $1.65 \pm 0.08 \% \mathrm{ID} / \mathrm{g}$ ), while its tumor-to-normal organ contrast ratios in all cases were better than both, $\mathbf{1}$ and $\mathbf{2}$. Regarding normal organ biodistribution, 2 showed rapid renal excretion and low activity levels in blood, liver, and intestines. Renal excretion rates were initially comparable for both $\mathbf{1}$ and $\mathbf{2}$, with monomer 1 showing higher excretion rates with time, while 2 remained in the kidneys. The tetrameric ligand, 3 , showed intermediate clearance kinetics, predominant renal excretion, and lower unspecific tissue distribution, while its liver uptake was lower than that of $\mathbf{1}$ and 2. However, $\mathbf{3}$ showed significant metabolization, especially in liver, kidney, and tumor, which according to the authors was due to the effect of lysine linkers, which are present between PEG and Dpr groups, cleaving the ligand's bridging to monomeric and dimeric units.

Chen et al. labeled with ${ }^{18} \mathrm{~F}$ the dimeric peptide $\mathrm{E}[\mathrm{c}(\mathrm{RGDyK})]_{2}$ (Figure 3) acylating the alpha $-\mathrm{NH}_{2}$ group of the glutamate (E) linker (using $\mathrm{N}$-succinimidyl $4-\left[{ }^{18} \mathrm{~F}\right]$ fluorobenzoate: $\left.\left[{ }^{18} \mathrm{~F}\right] \mathrm{SFB}\right), 4$, while the alpha and side-chain - $\mathrm{COOH}$ groups were conjugated to the $\mathrm{K}$ of each pentapeptide $\mathrm{c}(\mathrm{RGDyK})$ [34]. The resulting dimeric peptide $\left[{ }^{18} \mathrm{~F}\right] \mathrm{FB}-\mathrm{E}[\mathrm{c}(\mathrm{RGDyK})]_{2}$, 4 showed higher uptake for primary human brain capillary endothelial cells (HBCECs) expressing integrin $\alpha_{\mathrm{v}} \beta_{3}\left(\mathrm{IC}_{50}=2.3 \pm 0.7 \mathrm{nM}\right)$ compared to the monomeric analogue $\left[{ }^{18} \mathrm{~F}\right] \mathrm{FB}-\mathrm{c}(\mathrm{RGDyK})\left(\mathrm{IC}_{50}=3.5 \pm 0.3 \mathrm{nM}\right)$. When 4 , was administered to glioblastoma xenograft mouse model U87MG for micro-PET, autoradiographic imaging, direct tissue it showed significantly higher tumor uptake, and prolonged tumor retention in comparison to the monomer (120 min p.i. 4: $4.27 \pm 1.04 \% \mathrm{ID} / \mathrm{g}$, monomer: $1.56 \pm 0.35 \% \mathrm{ID} / \mathrm{g}$ ). Additionally, the dimeric structure 4 showed predominant renal excretion, whereas the monomeric analog was excreted primarily through the biliary route, which during microPET imaging resulted in much higher tumor to contralateral background ratios. The 
superior imaging characteristics of 4 were attributed to the synergistic effect of poly-valency and improved pharmacokinetics [34].

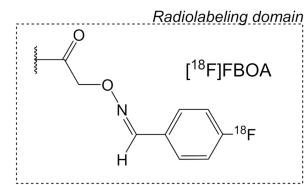

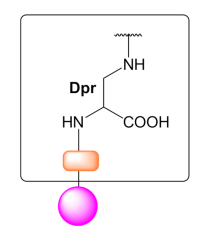

$\left[{ }^{18} \mathrm{~F}\right] F B O A-D p r-H E G-c(R G D F)$

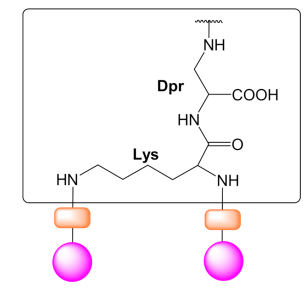

$\left[{ }^{18} \text { F]FBOA-Dpr-K-[HEG-c(RGDfE) }\right]_{2}$

2

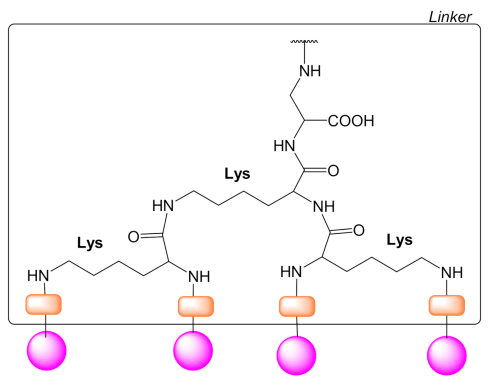

$\left.\left[{ }^{18} \text { F]FBOA-Dpr-K\{K-[HEG-c(RGDfE) }\right]_{2}\right\}_{2}$

3
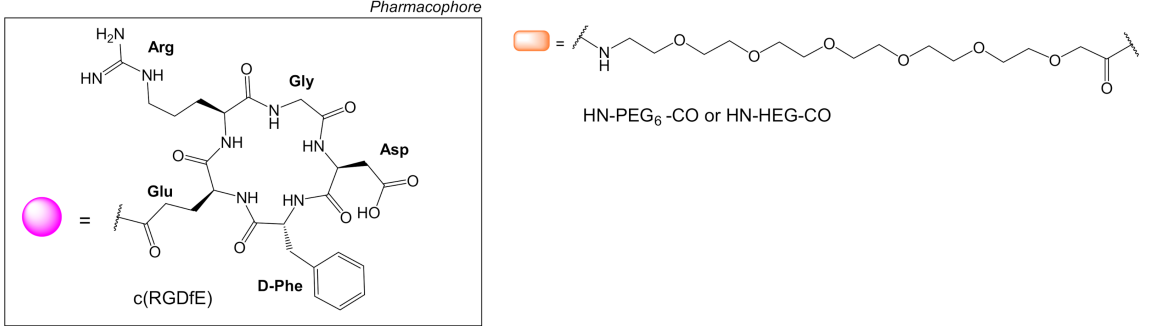

Figure 2. Chemical structures of $\mathrm{c}(\mathrm{RGDfE})$ peptides with a $\mathrm{PEG}_{6}$ linker $\left(\mathrm{H}_{2} \mathrm{~N}-\mathrm{PEG}_{6}\right.$ $\mathrm{CH}_{2} \mathrm{COOH}$ ); monomer $\left[{ }^{18} \mathrm{~F}\right]$ FBOA-Dpr-HEG-c(RGDfE) 1, dimer $\left[{ }^{18} \mathrm{~F}\right]$ FBOA-Dpr-K(HEG$\mathrm{c}($ RGDfE $))_{2} 2$ and tetramer $\left[{ }^{18} \mathrm{~F}\right] \mathrm{FBOA}-\mathrm{Dpr}-\mathrm{K}\left\{\mathrm{K}\left[\mathrm{HEG}-(\mathrm{c}(\mathrm{RGDfE})]_{2}\right\}_{2} 3\right.$ are labeled with $\mathrm{N}$-(4$\left[{ }^{18} \mathrm{~F}\right]$ fluorobenzylidene)oxime $\left(\left[{ }^{18} \mathrm{~F}\right] \mathrm{FBOA}\right)(\mathrm{Dpr}=$ diaminopropionic acid $)$.
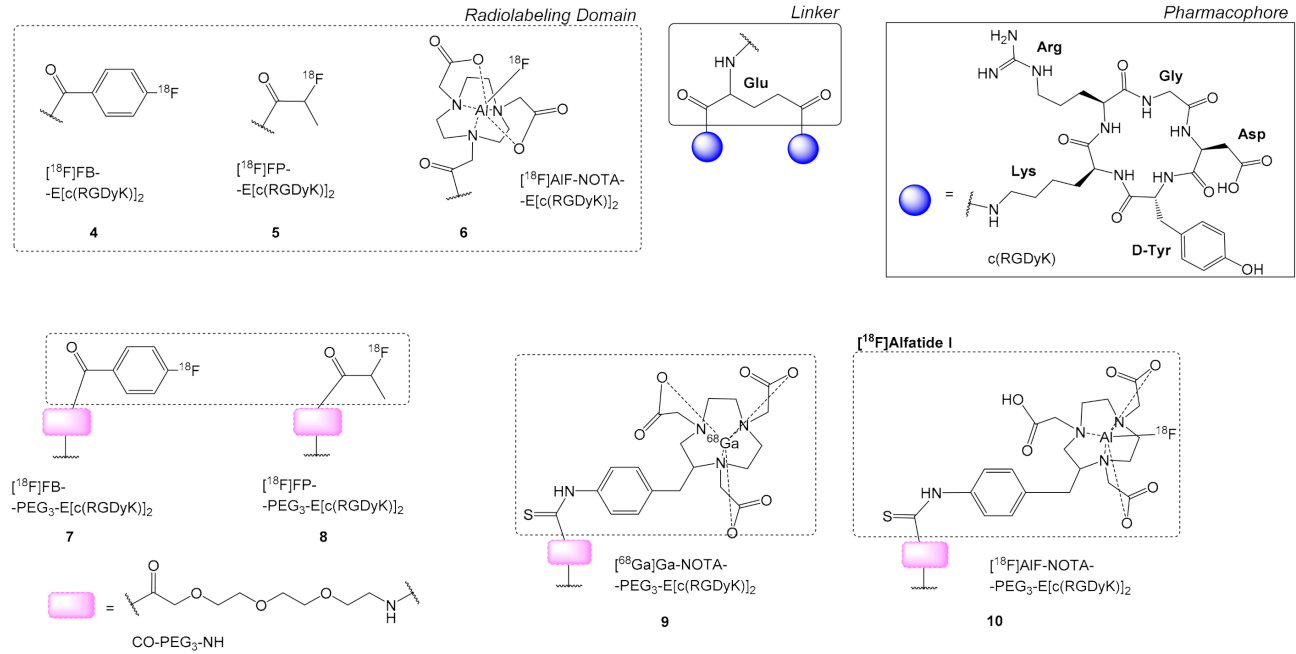

Figure 3. Chemical structures of dimeric radioligands containing the scaffold $E(c(R G D y K)]_{2}$ without: $\left[{ }^{18} \mathrm{~F}\right] \mathrm{FB}-\mathrm{E}[\mathrm{c}(\mathrm{RGDyK})]_{2} \mathbf{4}$, and $\left[{ }^{18} \mathrm{~F}\right] \mathrm{FP}-\mathrm{E}[\mathrm{c}(\mathrm{RGDyK})]_{2}{ }_{2},\left[{ }^{18} \mathrm{~F}\right] \mathrm{AlF}-\mathrm{NOTA}-\mathrm{E}[\mathrm{c}(\mathrm{RGDyK})]_{2}$ 6, and with a $\mathrm{PEG}_{3}$ group in between the alpha $\mathrm{H}_{2} \mathrm{~N}$ - group of $\mathrm{E}$ and the radiolabeled domain: $\left[{ }^{18} \mathrm{~F}\right] \mathrm{FB}-\mathrm{PEG}_{3}-\mathrm{E}[\mathrm{c}(\mathrm{RGDfK})]_{2} 7,\left[{ }^{18} \mathrm{~F}\right] \mathrm{FP}-\mathrm{PEG}_{3}-\mathrm{E}[\mathrm{c}(\mathrm{RGDfK})]_{2} 8,\left[{ }^{68} \mathrm{Ga} \mathrm{Ga}-\mathrm{NOTA}-\mathrm{PEG}_{3}-\mathrm{E}[\mathrm{c}(\mathrm{RGDyK})]_{2}\right.$ 9, $\left[{ }^{18} \mathrm{~F}\right]$ AlF-NOTA-PEG $3-\mathrm{E}[\mathrm{c}(\mathrm{RGDyK})]_{2}$ or $\left[{ }^{18} \mathrm{~F}\right]$ Alfatide I $10\left(\mathrm{H}_{2} \mathrm{~N}-\mathrm{PEG}_{3}-\mathrm{COOH}=11\right.$-amino-3,6,9trioxaundecanoic acid). 
The same dimeric scaffold $\mathrm{E}[\mathrm{c}(\mathrm{RGDyK})]_{2}$ was also used for the synthesis of other multimers e.g., the $\left[{ }^{18} \mathrm{~F}\right] \mathrm{FP}-\mathrm{E}[\mathrm{c}(\mathrm{RGDyK})]_{2} 5$, in which the $2-{ }^{18} \mathrm{~F}$-fluoropropionate $\left(\left[{ }^{18} \mathrm{~F}\right] \mathrm{FP}\right)$ is attached at the $\alpha$-amino group of the glutamate linker moiety [35]. One of the major obstacles in the clinical translation of radioligands like 4 or 5 , is the laborious multistep ${ }^{18} \mathrm{~F}$ installation in the dimeric structure, which includes a four-step, two-pot procedure with a long reaction time [34,35]. In this context, Liu et al. [35] described the synthesis of $\left[{ }^{18} \mathrm{~F}\right] \mathrm{AlF}-$ NOTA-E $\left[(\mathrm{c}(\mathrm{RGDyK})]_{2}\right.$ or $\left[{ }^{18} \mathrm{~F}\right] \mathrm{AlF}-\mathrm{NOTA}-\mathrm{RGD}_{2} \mathbf{6}$, (NOTA = 1,4,7-triazacyclononane-1,4,7triacetic acid), using the $\mathrm{Al}^{18} \mathrm{~F}$ intermediate (Figure 3) in a shorter time with good radiochemical yield ( $>17.9 \%)$. Integrin $\alpha_{\mathrm{v}} \beta_{3}$ binding avidity of 6 was assessed in the U87MG cell model resulting in an $\mathrm{IC}_{50}=46 \pm 4.4 \mathrm{nM}$. The tumor-targeting efficacy and in vivo profile of 6 and 5 were further evaluated in the same model by microPET and biodistribution. Interestingly, the two radioligands $\mathbf{5}$ and $\mathbf{6}$ had similar biodistribution and imaging properties, showing fast clearance from the body, and high tumor to normal organ contrast ratios. However, 6 showed slightly higher tumor uptake than 5 (120 min p.i.: $2.3 \pm 0.9 \%$ ID/g instead of $1.3 \pm 0.8 \% \mathrm{ID} / \mathrm{g}$, respectively) [35].

\subsection{PEG Linkers on ${ }^{18}$ F Labeled Cyclic RGD Multimers}

Following the example of Poethko et al. [22,33] who introduced a long PEG $_{6}$ group the Lys linker with the $\mathrm{c}(\mathrm{RGD})$ pharmacophores, shorter PEGs were introduced in between the linker and the labeling domain. The introduction of PEG spacer groups between the pharmacophores and the labeling domain improved the overall radiolabeling yield and the radioligands pharmacokinetics. Specifically, PEGs were introduced between the amino acid linker (E or $\mathrm{K})$ and the radiolabeling domain and/or between the linker and the pharmacophores (Figure 3, 6). For example, when a $\mathrm{PEG}_{3}$ was introduced in the structure of 4 , resulting in compound $\left[{ }^{18} \mathrm{~F}\right] \mathrm{FB}-\mathrm{PEG}_{3}-\mathrm{E}(\mathrm{cRGDyK})_{2}$ or $\left[{ }^{18} \mathrm{~F}\right] \mathrm{FB}-\mathrm{PRGD}_{2} 7$ it increased the radiochemical yield (Yield $>60 \%$ and purity $>99 \%$ ) [36]. In addition, 7 showed an improved pharmacological profile compared to 4 , since it showed higher receptor binding avidity 7 $\left(\mathrm{IC}_{50}=40.6 \pm 4.6 \mathrm{nM}\right), 4\left(\mathrm{IC}_{50}=55.1 \pm 6.5 \mathrm{nM}\right)$, higher metabolic stability, similar integrin $\alpha_{\mathrm{v}} \beta_{3}$-specific tumor uptake (U87MG glioma xenograft model, $30 \mathrm{~min}$ p.i.: $4.9-5 \% \mathrm{ID} / \mathrm{g}$ ) and reduced renal uptake 7 (60 $\mathrm{min}: 2.0 \pm 0.2 \% \mathrm{ID} / \mathrm{g}$ ), 4 (60 $\mathrm{min}: 3.0 \pm 0.2 \% \mathrm{ID} / \mathrm{g}$ ) [36]. The reproducibility of $\left[{ }^{18} \mathrm{~F}\right]$ FP-PRGD 7 as an integrin $\alpha_{\mathrm{v}} \beta_{3}$-targeting PET probe was also verified using a small animal PET and mouse tumor xenograft (human HCT116 colon cancer) model. During those studies, 7 showed reproducible results with relatively low variability [37].

Rokugawa et al. investigated radioligand $\left[{ }^{18} \mathrm{~F}\right] \mathrm{FP}-\mathrm{PEG}_{3}-\mathrm{E}[\mathrm{c}(\mathrm{RGDyK})]_{2} 8$ for PET scanning of fibrosis in non-alcoholic steatohepatitis (NASH) pathology through detecting hepatic integrin $\alpha_{\mathrm{v}} \beta_{3}$ expression in NASH [27]. C57BL/6 mice were fed with a cholinedeficient, L-amino acid-defined, high-fat diet, which after some time ( 3,8 weeks) produced moderate-to-severe steatosis and inflammation of the liver. PET scanning revealed that the hepatic uptake of 8 correlated well with integrin $\alpha_{\mathrm{v}} \beta_{3}$ expression and histological fibrosis in a mouse model of NASH, suggesting the predictability of fibrosis in NASH pathology [27].

Lang et al. compared $\left[{ }^{18} \mathrm{~F}\right]$ FP-PEG $3-\mathrm{E}[\mathrm{c}(\mathrm{RGDyK})]_{2} 8$ with $\left[{ }^{68} \mathrm{Ga}\right] \mathrm{Ga}-\mathrm{NOTA}-\mathrm{PEG}_{3}$ $\mathrm{E}[\mathrm{c}(\mathrm{RGDyK})]_{2} 9$ and $\left[{ }^{18} \mathrm{~F}\right]$ AlF-NOTA-PEG $3-\mathrm{E}[\mathrm{c}(\mathrm{RGDyK})]_{2} \mathbf{1 0}$ (also called $\left[{ }^{18} \mathrm{~F}\right]$ Alfatide) [38], where the NOTA chelator replaced the $\left.{ }^{18} \mathrm{~F}\right] \mathrm{FP}$ group enabling the labeling with a radiometal. Specifically, the $p$-SCN-Bn-NOTA chelator group (2-S-(4-Isothiocyanatobenzyl)1,4,7-triazacyclononane-1,4,7-triacetic acid) was attached to the Glu linker via a $\mathrm{PEG}_{3}$ spacer resulting in a thioamide bond between $\mathrm{PEG}_{3}$ and NOTA (Figure 3). Radiolabeling procedure for 9 and 10 through complexation with ${ }^{68} \mathrm{Ga}$ and $\mathrm{Al}^{18} \mathrm{~F}$, was much easier and resulted in high yields, i.e., $\mathbf{8}(10-15 \%), \mathbf{9}(5-25 \%), \mathbf{1 0}(75 \%)$ [38]. All three compounds 8-10 showed similar in vitro binding affinities $\left(\mathrm{IC}_{50} 8: 175.4 \mathrm{nM}, 9: 119.2 \mathrm{nM}, 10: 82.7 \mathrm{nM}\right.$ ), and in vivo rapid and high tracer uptake in U87MG tumors with high target-to-background ratios. Radioligands $\mathbf{9}$ and $\mathbf{1 0}$ showed imaging properties and pharmacokinetics comparable to 8 in U87MG-xenografted mice, with 10 showing slightly higher tumor uptake [38]. Comple- 
mentary to the above results during quantitatively PET imaging studies (U87MG human glioblastoma) ligands 8-10 presented insignificant differences, although $\mathbf{1 0}$ again showed a slightly higher binding potential and specific distribution volume in the tumor [39].

$\left[{ }^{18} \mathrm{~F}\right]$ Alfatide, $\mathbf{1 0}$ were studied as a predictor of anti-angiogenic response in alveolar adenocarcinoma (A549, high angiogenesis) and prostate cancer (PC-3, low angiogenesis) animal models, at baseline and after treatment with an anti-angiogenic drug (apatinib, bevacizumab) or without (control). The evaluation index for the inhibition of tumor growth in the individuals in the treated groups was represented by the treatment/control (T/C) ratio (\%). Anti-angiogenic responses were denoted by the changes in uptake of $\mathbf{1 0}$ in the same animal. Uptake of $\mathbf{1 0}$ in the A549 models was significantly higher than in the PC-3 models (SUV mean A549: $0.64 \pm 0.07$ and PC-3: $0.25 \pm 0.02)$ and the same was true for T/N ratios (A549: $2.76 \pm 0.62$ and PC-3: $0.82 \pm 0.11$ ), before treatment. After anti-angiogenic treatment tumor growth was suppressed resulting in lower tumor/control values for the A549 xenografted tumors than the PC-3 tumors (apatinib, A549: $47 \pm 11.46$ and PC-3: $69 \pm 26.74 \%$; bevacizumab, A549: $57.80 \pm 13.82$ and PC-3: $90.27 \pm 13.09 \%$, respectively) In addition to the decreased $\left[{ }^{18} \mathrm{~F}\right]$ Alfatide $\mathbf{1 0}$ uptake in tumors after treatment, the degree of tumor response was also associated with the tumor uptake prior to treatment, indicating that $\left[{ }^{18} \mathrm{~F}\right]$ Alfatide PET may be a useful molecular imaging tool for individual patient selection prior to anti-angiogenic drug therapy [40].

In another study, $\mathbf{1 0}$ was stereotactically compared with ${ }^{18}$ F-fluorodeoxyglucose $\left(\left[{ }^{18} \mathrm{~F}\right] \mathrm{FDG}\right)$ and immunohistochemistry (IHC) staining in Lewis lung carcinoma (LLC) tumor-bearing C57BL/ 6 mouse model. Tumor-to-brain, tumor-to-lung, and tumor-to-heart ratios of 10 were significantly higher than those of $\left[{ }^{18} \mathrm{~F}\right] \mathrm{FDG}(p<0.001)$. The spatial heterogeneity of the tumors was detected, and the tracer accumulation enhanced from the outer layer to the inner layer consistently. The different SUVs in the different tumor areas represent different levels of angiogenesis and probably deserve different radiation doses for tumor control. Correlations were found between: 1) SUVRGD and the $\alpha_{\mathrm{V}} \beta_{3}$ expression in tumors $(R=0.595, p=0.019)$ and 2$) S_{\text {FDG }}$ and $\operatorname{SUV}_{\mathrm{RGD}}(R=0.917, p<0.001)$. The latter corresponded to the IHC findings for the expression levels of glucose transporter proteins and $\alpha_{\mathrm{v}} \beta_{3}$, which were also correlated $(R=0.637, p=0.011)$ [41].

The introduction of $\mathrm{PEG}_{4}$ (15-amino-4,7,10,13-tetraoxapentadecanoic acid) in the linker was another very popular choice for the synthesis of c(RGD) multimers. A PEG 4 group was introduced either in between the alpha-amino group of the Glu linker (ligands 11-13) and/or connecting with amide bonds each of the pharmacophore groups (ligands 14-16) (Figure 4). Among those radioligands, the most studied is $\left[{ }^{18} \mathrm{~F}\right] \mathrm{AlF}-\mathrm{NOTA}-\mathrm{E}\left[\mathrm{PEG}_{4}{ }^{-}\right.$ $\mathrm{c}(\mathrm{RGDfK})]_{2}$ or $\left[{ }^{18} \mathrm{~F}\right]$ Alfatide II 14, which is considered an improved version of $\left[{ }^{18} \mathrm{~F}\right] \mathrm{AlF}-$ NOTA-PEG $3-E[c(R G D y K)]_{2}$ or $\left[{ }^{18} \mathrm{~F}\right]$ Alfatide I regarding its production process and its stability afterward.

$\left[{ }^{18} \mathrm{~F}\right]$ Alfatide II 14 was compared to $\left[{ }^{18} \mathrm{~F}\right] \mathrm{FDG}$ for parametric monitoring of tumor therapy response to doxorubicin (U87MG tumors) and paclitaxel (MDA-MB-435 tumors) protein-bound particles through a dual tracer imaging approach. The parameters fitted with compartmental modeling from the dual-tracer dynamic imaging were consistent with those from single-tracer imaging, substantiating the feasibility of this methodology. Moreover, dual-tracer imaging was able to measure 14 binding potential value and [ $\left.{ }^{18} \mathrm{~F}\right] \mathrm{FDG}$ influx simultaneously to evaluate tumor angiogenesis and metabolism. Such changes are known to precede anatomic changes, offering the promise of early prediction of therapy response with this method [42]. 14 could also monitor early treatment response and predict the therapeutic efficacy of the multi-targeted, anti-angiogenic drug sunitinib in U87MG tumors [43]. Finally, 14 was also evaluated on muscular inflammation [44].

A comparison between the dimeric peptide $\left[{ }^{18} \mathrm{~F}\right] \mathrm{FP}-\mathrm{PEG}_{4}-\mathrm{E}[\mathrm{c}(\mathrm{RGDfK})]_{2}$ (or $\left[{ }^{18} \mathrm{~F}\right] \mathrm{FP}-$ $\mathrm{PRGD}_{2}$ ) 11, with $\left[{ }^{18} \mathrm{~F}\right] \mathrm{FP}-\mathrm{PEG}_{4}-\mathrm{E}\left[\mathrm{PEG}_{4}-\mathrm{c}(\mathrm{RGDfK})\right]_{2}$ (or $\left.\left[{ }^{18} \mathrm{~F}\right] \mathrm{FP}-\mathrm{PPRGD}{ }_{2}\right)$ 16, [45] showed a higher radiolabeling yield for 16 (55 $\pm 12 \%)$ than $11(25 \pm 11 \%)$, because of the additional $\mathrm{PEG}_{4}$ spacers, which decreased the steric hindrance during the addition of the prosthetic group. In vitro testing (U87MG cells) showed slightly improved avidity for 16 
$\left(\mathrm{IC}_{50}=35.8 \pm 4.3 \mathrm{nM}\right)$ in comparison to 11 ( $\left.\mathrm{IC}_{50}=47.4 \pm 5.8 \mathrm{nM}\right)$. In vivo comparison of 16 and 11 in U87MG human glioblastoma and MDA-MB-435 human melanoma tumor xerographs in mice, also favored 16, which presented higher U87MG-tumor uptake at all-time points studied (e.g., 16: $5.32 \pm 0.36 \% \mathrm{ID} / \mathrm{g}$ vs. 11: $3.02 \pm 0.44 \% \mathrm{ID} / \mathrm{g}, 30 \mathrm{~min}$ ) and tumor-to-non-tumor background ratios. MicroPET imaging for 16 corresponded to the results of the biodistribution. In addition, micro-PET imaging in the 4T1 murine breast cancer model, which expresses integrin only on the vasculature, confirmed explicit binding of $\mathbf{1 6}$ in the tumor vasculature [45].

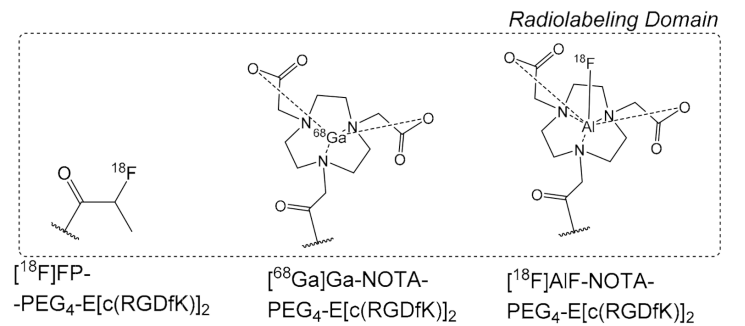

11

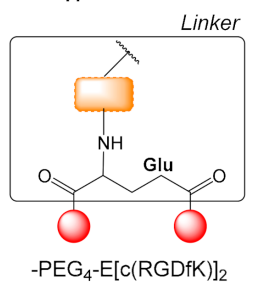

12

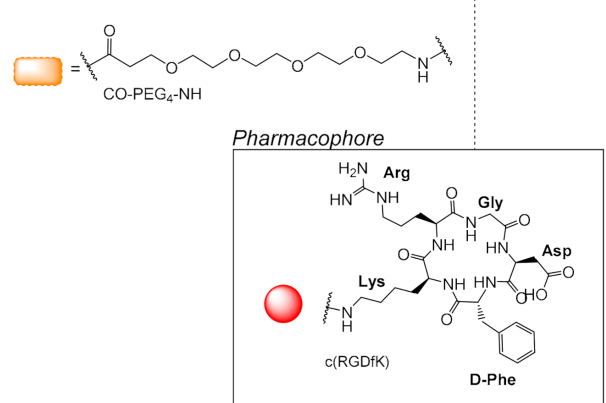

[18 F]Alfatide II

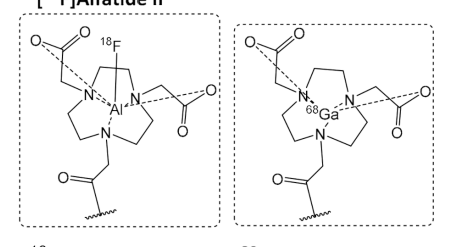

$\left[{ }^{18} \mathrm{~F}\right] A I F-N O T A-\quad\left[{ }^{68} \mathrm{Ga}\right] \mathrm{Ga}-N O T A-$ $\mathrm{E}\left[\mathrm{PEG}_{4}-\mathrm{C}(\mathrm{RGDfK})\right]_{2} \quad \mathrm{E}\left[\mathrm{PEG}_{4}-\mathrm{c}(\mathrm{RGDFK})\right]_{2}$ 15
16
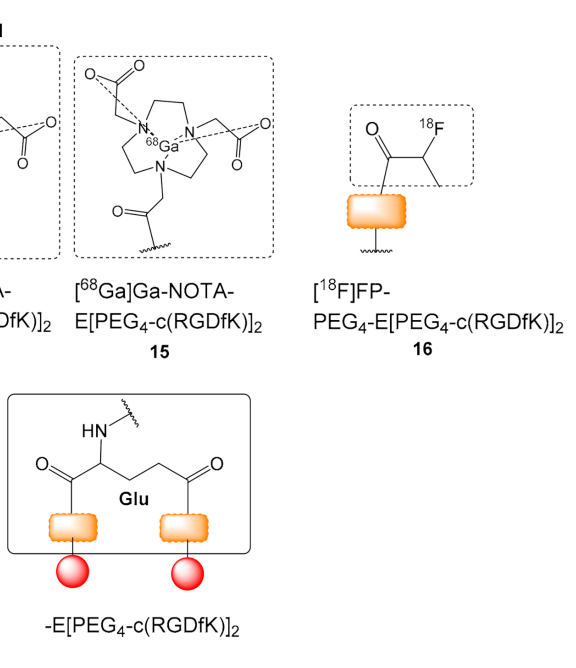

$-E\left[P G_{4}-C(R G D f K)\right]_{2}$

Figure 4. Chemical structures of $\mathrm{c}(\text { RGDfK) }]_{2}$ analogues with $\mathrm{PEG}_{4}$ spacers; $\left[{ }^{18} \mathrm{~F}\right] \mathrm{FP}-\mathrm{PEG}_{4}-\mathrm{E}[\mathrm{c}(\mathrm{RGDfK})]_{2}$ 11, $\left[{ }^{68} \mathrm{Ga}\right] \mathrm{Ga}-\mathrm{NOTA}-$ $\mathrm{PEG}_{4}$-E $\left[\mathrm{c}(\text { RGDfK) }]_{2} \text { 12, }\left[{ }^{18} \mathrm{~F}\right] \text { AlF-NOTA-PEG } 4 \text {-c (RGDfK) }\right]_{2}$ 13, $\left[{ }^{18} \mathrm{~F}\right]$ AlF-NOTA-E[PEG 4 -c(RGDfK) $]_{2}$ or $\left[{ }^{18} \mathrm{~F}\right]$ Alfatide II 14, $\left[{ }^{68} \mathrm{Ga}\right] \mathrm{Ga}-\mathrm{NOTA}-\mathrm{E}\left[\mathrm{PEG}_{4} \text {-c }(\text { RGDfK })\right]_{2}$ 15, $\left[{ }^{18} \mathrm{~F}\right] \mathrm{FP}-\mathrm{PEG}_{4}$-E[PEG 4 -c (RGDfK) $]_{2}, 16$ (HN-PEG 4 -COOH = 15-amino-4,7,10,13tetraoxapentadecanoic acid).

Guo et al. compared three radioligand dimers bearing $\left[{ }^{18} \mathrm{~F}\right] \mathrm{AlF}-\mathrm{NOTA}:\left[{ }^{18} \mathrm{~F}\right] \mathrm{AlF}-$ NOTA-E $\left[c(\text { RGDfK) }]_{2}\right.$ 6, without PEG groups (Figure 3), $\left[{ }^{18} \mathrm{~F}\right]$ AlF-NOTA-PEG ${ }_{4}-E\left[c(\text { RGDfK) }]_{2}\right.$ 13 with one PEG $_{4}$ between the central glutamic acid and NOTA and $\left[{ }^{18} \mathrm{~F}\right]$ AlF-NOTA$\mathrm{E}\left[\mathrm{PEG}_{4}-\mathrm{c}(\mathrm{RGDfk})\right]_{2}$ or $\left[{ }^{18} \mathrm{~F}\right]$ Alfatide II 14 with two $\mathrm{PEG}_{4}$ groups connecting each $\mathrm{c}(\mathrm{RGD})$ pharmacophore to the central Glu linker [46]. The study proved the superiority of $\mathbf{1 4}$ over the other two. All three multimeric radioligands remained intact after 120 min incubation in mouse serum. Comparison of the cell-binding avidities in U87MG cells with the unlabeled dimer $\mathrm{E}[\mathrm{c}(\mathrm{RGDfK})]_{2}$ also favored $\mathbf{1 4}$ compared to 13 and $\mathbf{6}\left(\mathrm{E}[\mathrm{c}(\mathrm{RGDfK})]_{2}>\mathbf{1 4}>\mathbf{1 3}>\mathbf{6}\right)$. While all radioligands showed a rapid and relatively high uptake in U87MG tumors with satisfactory tumor-to-background ratios, $\mathbf{1 4}$ had the highest tumor uptake and the lowest accumulation in the liver [46].

The effects of a symmetric beta-Glu linker in combination with a $\mathrm{PEG}_{2}$ (3-(2-(2aminoethoxy)ethoxy)propanoic acid) connecting the $\beta$-glutamate's amino group with the radiolabeling domain were studied with the ${ }^{18} \mathrm{~F}$-labeled $\mathrm{c}(\mathrm{RGD})$ homodimeric peptide $\left[{ }^{18} \mathrm{~F}\right] \mathrm{FP}-\mathrm{PEG}_{2}-\beta-\mathrm{E}[\mathrm{c}(\mathrm{RGDyK})]_{2} 17$ (Figure 5) [47]. The protruding free PEG-amino group of the symmetric $\beta$-glutamate linker in $\mathrm{PEG}_{2}-\beta-\mathrm{E}[\mathrm{c}(\mathrm{RGDyK})]_{2}$ encountered less steric hindrance for the installation of $\left[{ }^{18} \mathrm{~F}\right] \mathrm{FP}$ compared to the asymmetric PEG- $\alpha-\mathrm{E}[\mathrm{c}(\mathrm{RGDyK})]_{2}$, resulting in a higher-yielding radiolabeling preparation of $\left[{ }^{18} \mathrm{~F}\right] \mathrm{FP}-\mathrm{PEG}_{2}-\beta-\mathrm{E}[\mathrm{c}(\mathrm{RGDyK})]_{2}$ 17 (c.a. $18 \pm 3 \%$, synthesis time $=110 \mathrm{~min}$ ) in comparison with the radioligand $\left[{ }^{18} \mathrm{~F}\right] \mathrm{FP}-$ $\mathrm{E}[\mathrm{c}(\mathrm{RGDyK})]_{2} 5$ (radiochemical yield $=10-15 \%$, synthesis time $=180 \mathrm{~min}$ ). Biodistribution studies for 17 showed good tumor uptake (30 min p.i.: $3.38 \pm 0.23 \% \mathrm{ID} / \mathrm{g}$; $60 \mathrm{~min}$ p.i.: 
2.68\% ID/g) in A549 mice xenografts, while PET imaging in PC-3 and A549 tumor xenographs showed slightly higher values for PC-3 than A549 (60 min p.i.: $3.38 \pm 0.44 \%$ $\mathrm{ID} / \mathrm{g}$ vs. $2.85 \pm 0.35 \% \mathrm{ID} / \mathrm{g}$, respectively). Radioligand 17 was rapidly cleared from the blood by predominately renal excretion and had good stability in vitro and in vivo [47]. However, a direct pharmacokinetic comparison with similar radioligands with asymmetric Glu linkers e.g., $\mathbf{1 1}$ was not attempted.

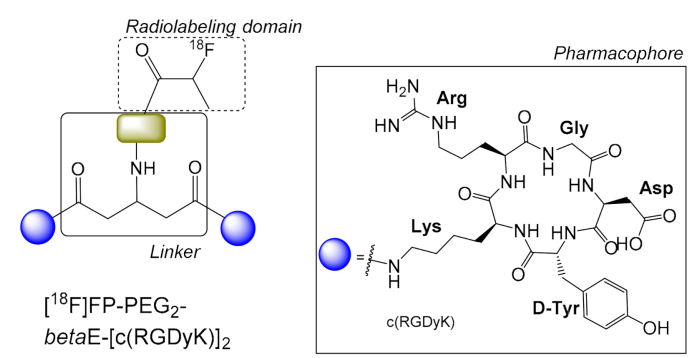

17

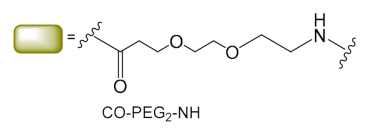

Figure 5. Chemical structure of the symmetric dimer $\left[{ }^{18} \mathrm{~F}\right] \mathrm{FP}-\mathrm{PEG}_{2}-\beta-\mathrm{E}[\mathrm{c}(\mathrm{RGDyK})]_{2}$ 17. $\left(\mathrm{H}_{2} \mathrm{~N}-\mathrm{PEG}_{2}-\right.$ $\mathrm{COOH}=3-(2-(2-a m i n o e t h o x y)$ ethoxy)propanoic acid).

\subsection{Sugar Amino Acid Linkers on ${ }^{18} F$ Labeled c(RGD) Multimers}

Other linker variations like galactose-based sugar amino acids have been also tested without any significant improvement [48]. In particular, the introduction of a galactosebased sugar amino acid spacer (SAA = 7-amino-L-glyero-L-galacto-2,6-anhydro-7deoxyheptanamide) in $\left[{ }^{18} \mathrm{~F}\right] \mathrm{FP}-\mathrm{SAA}-\mathrm{E}\left[\mathrm{c}(\mathrm{RGDyK})_{2}\right.$ 18, $\left[{ }^{18} \mathrm{~F}\right] \mathrm{FB}-\mathrm{SAA}-\mathrm{E}\left[\mathrm{c}(\mathrm{RGDyK})_{2}\right.$ 19, (Figure 6) resulted in superior pharmacokinetics than their monomeric analogs, but when 18-19 were compared to $\left[{ }^{18} \mathrm{~F}\right] \mathrm{FP}-\mathrm{PEG}_{3}-\mathrm{E}[\mathrm{c}(\mathrm{RGDfK})]_{2} \mathbf{8}$, which has a $\mathrm{PEG}_{3}$ linker, they all showed a similar pharmacokinetic profile [48]. However, the fact that the radiolabeling yield of 8 was substantially higher $(80 \%)$ than the yield of $\mathbf{1 8}(52 \%)$ with its laborious four-step synthesis; makes the $\mathrm{PEG}_{3}$ linkers a more useful and easily available choice.

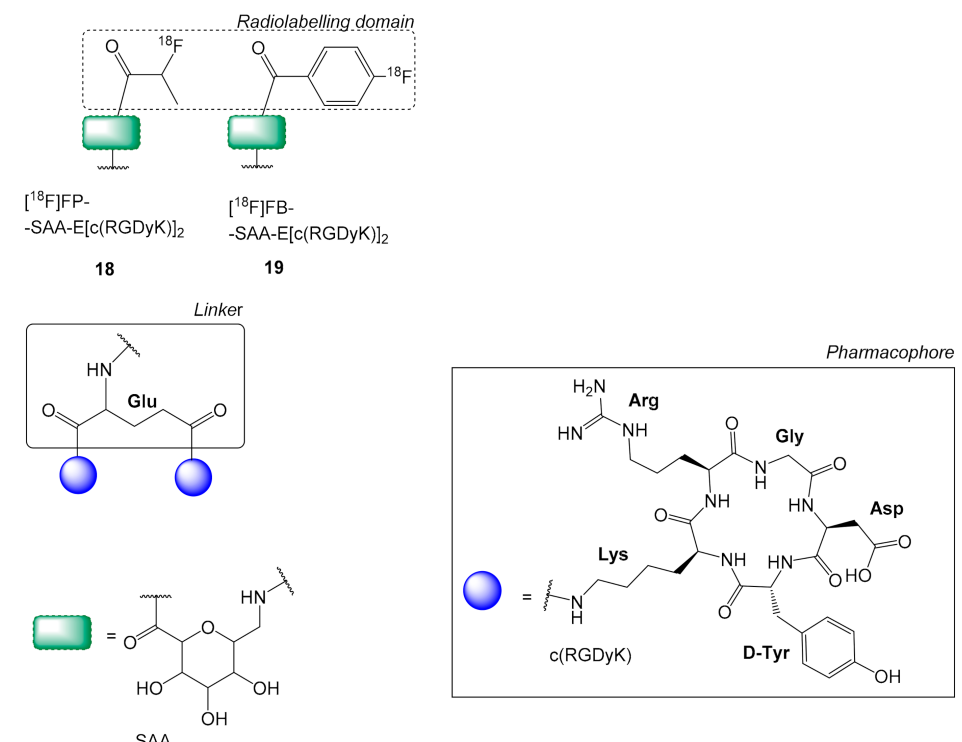

Figure 6. Chemical structures of $\left[{ }^{18} \mathrm{~F}\right] \mathrm{FP}-\mathrm{SAA}-\mathrm{E}\left[\mathrm{c}(\mathrm{RGDyK})_{2} \mathbf{1 8},\left[{ }^{18} \mathrm{~F}\right] \mathrm{FB}-\mathrm{SAA}-\mathrm{E}\left[\mathrm{c}(\mathrm{RGDyK})_{2}\right.\right.$ 19, where SAA = 7-amino-L-glyero-L-galacto-2,6-anhydro-7-deoxyheptanamide. 


\subsection{The Effect of Linkers on the Stability and Production of ${ }^{18}$ F Labeled Cyclic RGD Multimers}

While $\left[{ }^{18} \mathrm{~F}\right]$ Alfatide $\mathbf{1 0}$ was already in clinical studies, Lang et al. investigated the stability problems presented during its production [49]. The by-products observed during the production process were due to the neighboring of the glutamic acid to the $\alpha$-amine and thiurea groups, both participating in an intermolecular Lewis acid-catalyzed hydrolysis reaction under acidic conditions. Specifically, during the preparation of $\left[{ }^{68} \mathrm{Ga}\right] \mathrm{Ga}-$ NOTA-E(c(RGDyK) $]_{2} \mathbf{2 1}$ from 20 under acidic conditions and elevated temperature the nucleophilic addition of thiocarbonyl group of thiourea moiety at the neighboring carbonyl of the glutamic acid leads to the formation of a thiazolidinone ring in $\mathbf{2 0}$ and the release of $c$ (RGDfK) (Figure 7) [49]. The introduction of a PEG $_{3}$ spacer in $\left[{ }^{18} \mathrm{~F}\right]$ Alfatide I 10 increased the distance between the Glu linker and the thiourea group, reducing this phenomenon. However, when the NOTA chelator was linked to the dimer with a carboxamide bond, it minimized the oxidation of the thiourea motif resulting in a more stable compound: $\left[{ }^{18} \mathrm{~F}\right]$ AlF-NOTA-E[PEG $\left.{ }_{4}-\mathrm{c}(\mathrm{RGDfK})\right]_{2}$ or $\left[{ }^{18} \mathrm{~F}\right]$ Alfatide II 14. In $\left[{ }^{18} \mathrm{~F}\right]$ Alfatide II, the tyrosine of the cyclic RGD part was replaced by a D-phenylalanine, which is not oxidized by heating [50], while the two $\mathrm{PEG}_{4}$ groups introduced between each of the c(RGD) motifs and the Glu linker further increased the distance between the pharmacophores, enabling their simultaneous binding to the receptors [50]. It should be mentioned that $\mathbf{1 4}$ has also be radiolabeled using the kit formulation method [51-54].
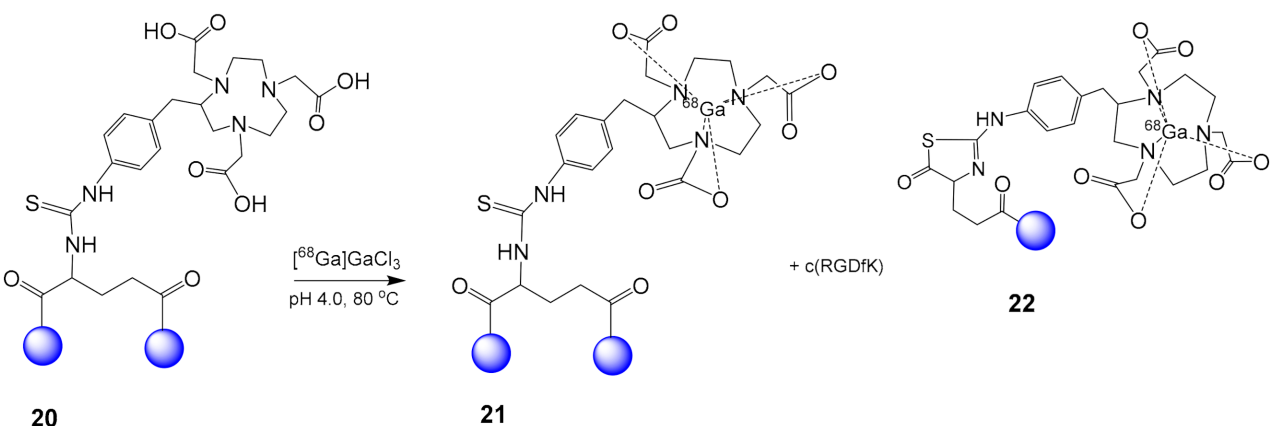

Figure 7. Instability of $\left[{ }^{68} \mathrm{Ga}\right] \mathrm{Ga}-\mathrm{NOTA}-\mathrm{E}(\mathrm{c}(\mathrm{RGDyK})]_{2} 21$ observed during its preparation from 20.

\section{5. ${ }^{64} \mathrm{Cu}$ Labeled $c(R G D)$ Multimers}

The introduction of chelator groups i.e., NOTA, DOTA (1,4,7,10-tetraazadodecane$\mathrm{N}, \mathrm{N}, \mathrm{N}, \mathrm{N}$-tetraacetic acid), facilitates the radiolabeling of c(RGD) multimers with various radionuclides; among them the positron-emitting PET radionuclide ${ }^{64} \mathrm{Cu}$ (half-life $=762 \mathrm{~min}$, $\left.\beta^{+} 17.9 \%, 0.64 \mathrm{MeV}\right)$, which can be produced from a biomedical cyclotron with various methods [31]. Radiolabeling is achieved by complexation of ${ }^{64} \mathrm{Cu}$ with the chelator group in mild conditions.

Chen et al. synthesized conjugates of the dimeric c(RGD) peptides $\mathrm{E}[\mathrm{c}(\mathrm{RGDyK})]_{2}$ and $\mathrm{E}[\mathrm{c}(\mathrm{RGDfK})]_{2}$ with the DOTA chelator, which were then complexed with ${ }^{64} \mathrm{Cu}$ [55]. Both radioligands $\left[{ }^{64} \mathrm{Cu}\right] \mathrm{Cu}-\mathrm{DOTA}-\mathrm{E}[\mathrm{c}(\mathrm{RGDfK})]_{2} 23$ and $\left[{ }^{64} \mathrm{Cu}\right] \mathrm{Cu}-\mathrm{DOTA}-\mathrm{E}[\mathrm{c}(\mathrm{RGDyK})]_{2}$ 25 (Figure 8) were used in biodistribution, micro-PET imaging, and whole-body autoradiography studies in athymic female nude mice with MDA-MB- 435 breast carcinoma xenografts. Radiotracers 23 and 25 showed specific $\alpha_{\mathrm{v}} \beta_{3}$ integrin tumor accumulation (i.e., $60 \mathrm{~min}$ p.i.: $3-4 \% \mathrm{ID} / \mathrm{g}$ ), with higher retention than previously tested monomeric c(RGD) radioligands. However, activity accumulation of $\mathbf{2 5}$ in tumors was significantly higher compared to the D-Phe analog 23. Liver uptake of the D-Tyr derivative $\mathbf{2 5}$ was lower than the D-Phe 23 derivative at early time points, but the difference became marginal with time. Generally, 25 yielded better PET images than 23 . The authors attributed this to the increased hydrophilicity of D-Tyr in 25 compared to D-Phe in 23 [55]. 

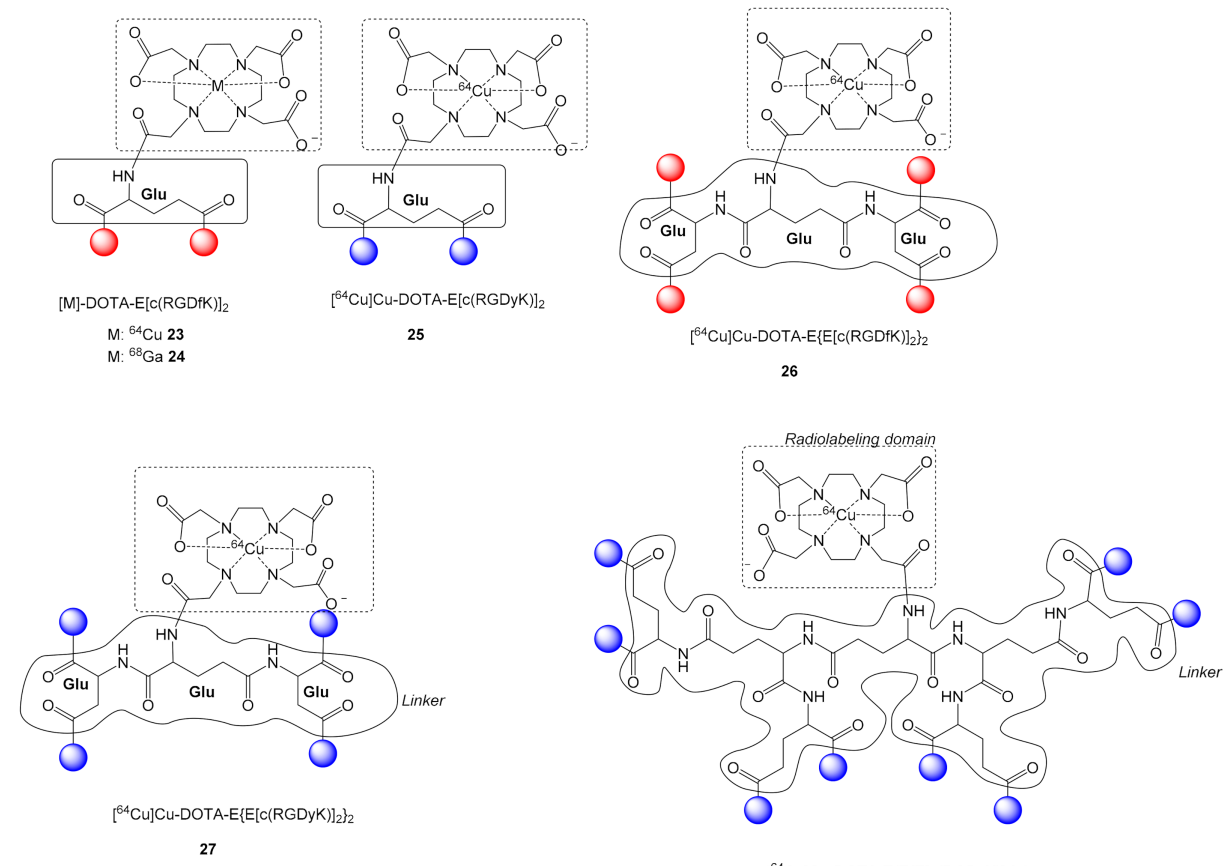

$\left[{ }^{64} \mathrm{Cu}\right] \mathrm{Cu}-\mathrm{DOTA}-\mathrm{E}\left(\mathrm{E}\left\{\mathrm{E}[\mathrm{C}(\mathrm{RGDyK})]_{2}\right\}_{2}\right)_{2}$
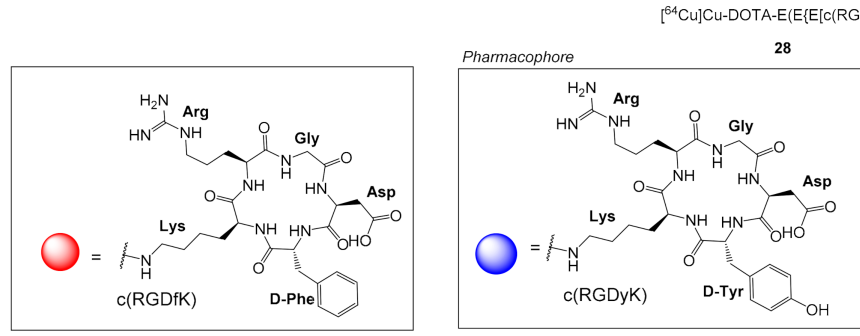

Figure 8. Chemical structures of ${ }^{64} \mathrm{Cu}$-labeled $\mathrm{c}(\mathrm{RGD})$ peptides with $(\mathrm{Glu})_{\mathrm{n}}$ linkers, $[\mathrm{M}]-\mathrm{DOTA}-\mathrm{E}[\mathrm{c}(\mathrm{RGDfK})]_{2}$, where $\mathrm{M}={ }^{64} \mathrm{Cu}: 23, \mathrm{M}={ }^{68} \mathrm{Ga}: 24,\left[{ }^{64} \mathrm{Cu}\right] \mathrm{Cu}-\mathrm{DOTA}-\mathrm{E}[\mathrm{c}(\mathrm{RGDyK})]_{2} 25$ and the $\mathrm{c}(\mathrm{RGD})$ tetramers $\left[{ }^{64} \mathrm{Cu}\right] \mathrm{Cu}-\mathrm{DOTA}-\mathrm{E}\left\{\mathrm{E}[\mathrm{c}(\mathrm{RGDfK})]_{2}\right\}_{2}$ 26 and $\left[{ }^{64} \mathrm{Cu}\right] \mathrm{Cu}-\mathrm{DOTA}-\mathrm{E}\left\{\mathrm{E}[\mathrm{c}(\mathrm{RGDyK})]_{2}\right\}_{2} 27$ and the cRGD octamer $\left[{ }^{64} \mathrm{Cu}\right] \mathrm{Cu}-\mathrm{DOTA}-\mathrm{E}\left(\mathrm{E}\left\{\mathrm{E}[\mathrm{c}(\mathrm{RGDfK})]_{2}\right\}_{2}\right)_{2} 28$.

Wu et al. synthesized the tetrameric c(RGD) peptidic radiotracer $\left[{ }^{64} \mathrm{Cu}\right] \mathrm{Cu}$-DOTA$\mathrm{E}\left\{\mathrm{E}[\mathrm{c}(\mathrm{RGDfK})]_{2}\right\}_{2} \mathbf{2 6}$ using a scaffold of three glutamic acid residues and compared it with the dimeric analog $\left[{ }^{64} \mathrm{Cu}\right] \mathrm{Cu}-\mathrm{DOTA}-\mathrm{E}\left[\mathrm{c}(\text { RGDfK) }]_{2} 23\right.$ (Figure 8) [56]. The $\mathrm{c}(\mathrm{RGD})$ tetramer 26 showed higher integrin-binding avidity $\left(\mathrm{IC}_{50}=16.6 \pm 1.3 \mathrm{nM}\right)$ in comparison to the corresponding dimeric analogue $23\left(\mathrm{IC}_{50}=48.4 \pm 2.8 \mathrm{nM}\right)$. Biodistribution and noninvasive microPET studies of tetramer $\mathbf{2 6}$ showed rapid, high and specific tumor uptake (U87MG) (30 min p.i.: $9.93 \pm 1.05 \% \mathrm{ID} / g$; 24 h p.i.: $4.56 \pm 0.51 \% \mathrm{ID} / \mathrm{g}$ ). Ligand 26 showed rapid blood clearance and predominantly renal excretion. The initial high tumor uptake and prolonged tumor retention of the tetramer were attributed to the high integrin avidity and the long blood circulation time, respectively. The latter was due to the increased molecular size. However, the enhanced tumor uptake of the tetramer $\mathbf{2 6}$ compared with the dimer $\mathbf{2 3}$ was accompanied by a similar increase in renal uptake, while tumor-to-kidney ratios did not increase significantly [56]. Consequently, the therapeutic/diagnostic advantage of a tetramer $\mathbf{2 6}$ over a dimer $\mathbf{2 3}$ might be modest.

$\mathrm{Li}$ et al. used a scaffold of seven glutamic acid residues to synthesize the c(RGD) octamer $\left.\left[{ }^{64} \mathrm{Cu}\right] \mathrm{Cu}-\mathrm{DOTA}\right]-\mathrm{E}\left(\mathrm{E}\left\{\mathrm{E}[\mathrm{c}(\mathrm{RGDyK})]_{2}\right\}_{2}\right)_{2} 28$ and compared it with the $\mathrm{c}(\mathrm{RGD})$ tetramer $\left[{ }^{64} \mathrm{Cu}\right] \mathrm{Cu}-\mathrm{DOTA}-\mathrm{E}\left\{\mathrm{E}[\mathrm{c}(\mathrm{RGDyK})]_{2}\right\}_{2} 27$ PET imaging of integrin $\mathrm{a}_{\mathrm{v}} \beta_{3}$ expressing tumors. [30] The $c(R G D)$ octamer 28 showed significantly higher binding avidity and specificity for integrin $\mathrm{a}_{\mathrm{v}} \beta_{3}\left(\mathrm{IC}_{50}=10 \mathrm{nM}\right)$ compared to the tetramer $27\left(\mathrm{IC}_{50}=35 \mathrm{nM}\right)$ (Figure 8). For 27, the distance between two distant c(RGD) pharmacophores is about 30 bond lengths, which is considered sufficient for simultaneous binding to adjacent integrin $a_{v} \beta_{3}$ receptors, while for the octamer 28 the distance is increased to 40 bond lengths, enabling simultaneous binding with two or more receptors. The octamer 28 showed higher 
tumor uptake and longer tumor retention compared to the tetramer 27 in both tumor models tested i.e., U87MG, 30 min p.i. 28: $11.7 \pm 0.7 \%$ ID/g, 27: $10.3 \pm 1.6 \%$ ID/g; c-neu onco-mice 60 min p.i. 28: $8.9 \pm 2.1 \%$ ID/g, 27: $4.4 \pm 0.9 \%$ ID/g), while the integrin $\mathrm{a}_{\mathrm{v}} \beta_{3}$ specificity of both tracers was confirmed by successful receptor-blocking experiments. However, a higher uptake and slow clearance in the kidneys was noted for 27, which was attributed to the integrin positivity of the kidneys, and to its larger molecular size [30]. The above studies indicate that the advantages observed for tetramers and octamers regarding receptor avidity and tumor uptake are counterweighted by their slow renal clearance, which eventually decreases their potential as diagnostic or therapeutic agents.

Hedhli et al. synthesized the dimeric c(RGD) radioligand $\left[{ }^{64} \mathrm{Cu}\right] \mathrm{Cu}-\mathrm{NOTA}-\mathrm{PEG}_{4}$ $\mathrm{E}\left[\left(\mathrm{PEG}_{2}-\mathrm{Tz}-\mathrm{c}(\mathrm{RGDFK})\right]_{2}\right.$ (Tz = triazole group) 29 (Figure 9) for application in PET imaging and the FITC-PEG $4-E\left[\left(\mathrm{PEG}_{2}-\mathrm{Tz}-\mathrm{c}(\mathrm{RGDfK})\right]_{2} 30\right.$ bearing a fluorescent group for in vitro studies [57]. Ligands 29 and $\mathbf{3 0}$ are similar to other previously mentioned multimeric c(RGD) peptides bearing PEG groups in the linker region, but they differed in the Tz group, which was formed using CuAAC instead of forming a peptide bond. The binding kinetics against $a_{v} \beta_{3}$ receptor were investigated using surface plasmon resonance. The association $\mathrm{K}_{\mathrm{on}}$ and dissociation $\mathrm{K}_{\mathrm{off}}$ constants of $\mathbf{2 9}$ and $\mathbf{3 0}$ and the commercially available monomeric $c(R G D y K)$ were investigated in immobilized $\alpha_{V} \beta_{3}$ receptors. The unlabeled dimeric peptide NOTA-PEG $4-E\left[\mathrm{PEG}_{2}-\mathrm{Tz}-\mathrm{c}(\mathrm{RGDfK})\right]_{2}$ corresponding to 27 , showed a binding avidity $\left(\mathrm{K}_{\mathrm{d}}=0.19 \mathrm{pM}\right)$, which was approximately 50 -fold higher than the binding affinity of the monomeric NOTA-c(RGDfK) $\left(\mathrm{K}_{\mathrm{d}}=9.6 \mathrm{pM}\right)$, while ${ }^{64} \mathrm{Cu}$ labeled 29 and FITC labeled 30 showed marginally reduced binding avidity with $\mathrm{K}_{\mathrm{d}}$ values $1.5 \mathrm{pM}$ and $8.6 \mathrm{pM}$, respectively. According to the authors, the receptor-bound dimeric c(RGD) peptides 29 and 30 dissociated from $\alpha_{V} \beta_{3}$ at a much slower rate $\left(k_{\text {off }}=2.1 \times 10^{-6} \mathrm{~s}^{-1}\right)$ compared to the typical adhesive proteins, e.g., the fibrinogen $\left(\mathrm{k}_{\mathrm{off}}=9.8 \times 10^{-4} \mathrm{~s}^{-1}\right)$ and the vibronectin $\left(\mathrm{k}_{\mathrm{off}}=2.1 \times 10^{-4} \mathrm{~s}^{-1}\right)$. In HUVEC cells (human umbilical vein endothelial cells) the binding affinities of $30\left(\mathrm{~K}_{\mathrm{d}}=38.27 \mathrm{nM}\right)$ and $29\left(\mathrm{~K}_{\mathrm{d}}=33.85 \mathrm{nM}\right)$ were comparable to the binding affinities of fibrinogen and vibronectin, which are $27 \mathrm{nM}$ and $64 \mathrm{nM}$, respectively. More importantly, the dissociation constant of the dimeric c(RGD) peptides 29 and $\mathbf{3 0}$ was approximately 20-fold lower than most monomeric c(RGD) peptides, and only 2.5-fold higher than the $\alpha_{V} \beta_{3}$ integrin's antibody LM609 $(\mathrm{Kd}=14.4 \mathrm{nM})$.

Compared to 29, Shi et al. investigated the replacement of the two $\mathrm{PEG}_{2}-\mathrm{Tz}$ with two $\mathrm{PEG}_{4}$ groups in the dimeric ligand $31\left[{ }^{64} \mathrm{Cu}\right] \mathrm{Cu}-\mathrm{DOTA}-\mathrm{PEG}_{4}-\mathrm{E}\left[\mathrm{PEG}_{4}-\mathrm{c}(\mathrm{RGDfK})\right]_{2}$ and the replacement of $\mathrm{PEG}_{4}$ and the two $\mathrm{PEG}_{2}-\mathrm{Tz}$ with $\mathrm{G}_{3}$ groups in dimer $32\left[{ }^{64} \mathrm{Cu}\right] \mathrm{Cu}-\mathrm{DOTA}-$ $\mathrm{G}_{3}-\mathrm{E}\left[\mathrm{G}_{3}-\mathrm{c}(\mathrm{RGDfK})\right]_{2}$ and also used a $\mathrm{COCH}_{2}$ instead of the $\mathrm{C}(=\mathrm{S}) \mathrm{NHC}_{6} \mathrm{H}_{4} \mathrm{CH}_{2}$ moiety connecting the chelator with the spacer-pharmacophore part of the radioligand (Figure 9). [58] The structural alteration marginally increased receptor avidity for $32\left(\mathrm{IC}_{50}=62 \pm 6 \mathrm{nM}\right)$, compared to $31\left(\mathrm{IC}_{50}=74 \pm 3 \mathrm{nM}\right)$. Dimers 31 and 32 were ${ }^{64} \mathrm{Cu}$-radiolabeled with high yields and specific activity being $>50 \mathrm{Ci} / \mathrm{mmol}$. Biodistribution studies showed a very similar kinetic profile for the two radiotracers regarding U87MG tumor uptake and clearance with the $\mathrm{PEG}_{4}$-based dimer $\mathbf{3 1}$ showing slightly faster blood clearance and lower kidney values [58].

Liu et al. synthesized two dimers $\left[{ }^{64} \mathrm{Cu}\right] \mathrm{Cu}-\mathrm{AmBaSar}-\mathrm{E}[\mathrm{c}(\mathrm{RGDyK})]_{2} 33$ and $\left[{ }^{64} \mathrm{Cu}\right] \mathrm{Cu}$ AmBaBaSar-c(RGDyK) 34 using the cage hexaazamacrobicyclic sarcophagine (Sar) chelator, for labeling with ${ }^{64} \mathrm{Cu}$ under mild conditions, in combination with the linker AmBa $(\mathrm{AmBa}=4-($ Aminomethyl)benzoic acid $)$. Ligands were formed by reacting 4bromomethylbenzoic acid with one $\mathbf{3 3}$ or both $\mathbf{3 4}$ amine groups of Sar protruding the cage cavity (Figure 10). After radiolabeling, the dimers were further evaluated in vitro and in vivo $[59,60]$. Radioligands 33 and $\mathbf{3 4}$ were proved very stable (intact tracer $>95 \%$ during HPLC analysis, 60 min after injection), both in vitro and in vivo and this was attributed to the cross bridged and cage-like configuration of the Sar chelator. Dimeric radioligand 33 showed higher tumor uptake than its respective monomeric, $(20 \mathrm{~h}$ p.i. 33: $1.76 \pm 0.38 \% \mathrm{ID} / \mathrm{g},\left[{ }^{64} \mathrm{Cu}\right] \mathrm{Cu}-\mathrm{AmBaSar}-\mathrm{c}(\mathrm{RGD}): 0.65 \pm 0.05 \%$ ID/g) and generally more favorable pharmacokinetics, due to the polyvalency effect [59]. However, the bi- 
functionalized Sar dimeric ligand 34 was proved superior to 33 both in vitro, by displaying higher avidity, i.e., 34: $\mathrm{IC}_{50}=6.0 \pm 0.9 \mathrm{nM}$, 33: $\mathrm{IC}_{50}=10.0 \pm 0.5 \mathrm{nM}$, and in vivo, by showing higher tumor uptake i.e., $1 \mathrm{~h}$ p.i $33: 3.04 \pm 0.25 \% \mathrm{ID} / \mathrm{g}, 34: 6.16 \pm 0.88 \% \mathrm{ID} / \mathrm{g}$. The difference according to the authors was due to the distance between the two pharmacophores, which is 5 bonds (Glu linker) in the case of 33, while it is 22 covalent bonds in 34 due to the intervention of the AmBaBaSar group (Figure 10). Thus, in 33 the simultaneous binding on two integrin receptors was less likely compared to 34 , where the increased distance and flexibility permit such binding interactions [59,60].

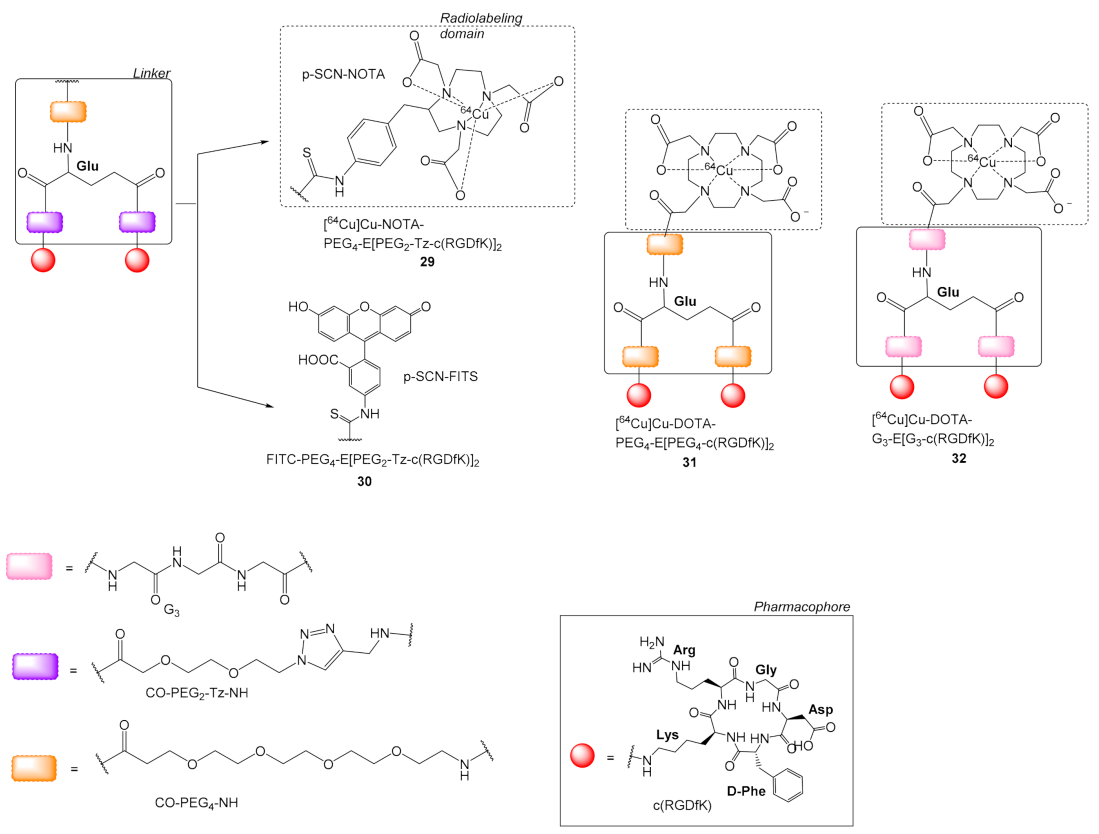

Figure 9. Chemical structures of ${ }^{64} \mathrm{Cu}$ and FITC labeled c(RGD) peptides with the Tz-PEG 2 spacers 29 and 30, respectively $(\mathrm{Tz}=$ triazole group, FITC = Fluorescein isothiocyanate isomer $\mathrm{I})$ and with $\mathrm{PEG}_{4} 31$ and $\mathrm{G}_{3} 32$.
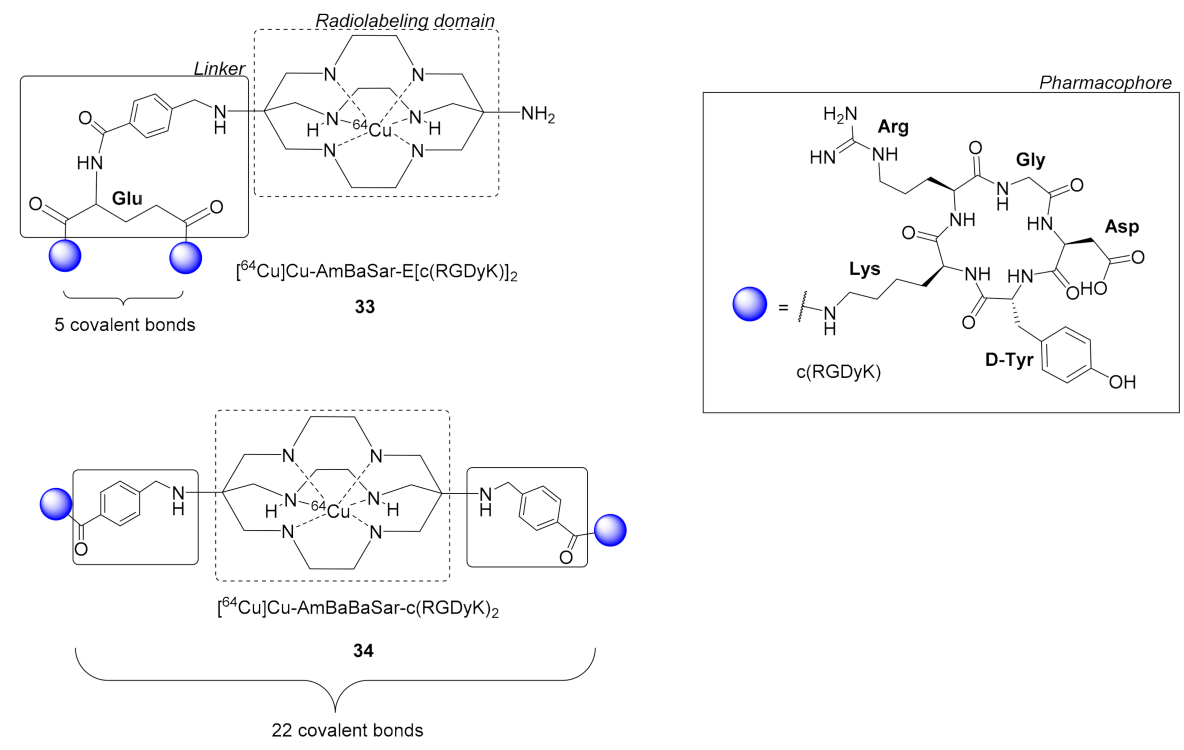

Figure 10. Dimeric $c(R G D y K)_{2}$ radioligands $\left[{ }^{64} \mathrm{Cu}\right] \mathrm{Cu}-\mathrm{AmBaSar}-\mathrm{E}[\mathrm{c}(\mathrm{RGDyK})]_{2} 32$ and $\left[{ }^{64} \mathrm{Cu}\right] \mathrm{Cu}$ AmBaBaSar-c(RGDyK) 33 bearing the hexaazamacrobicyclic sarcophagine (Sar) chelator, $\mathrm{AmBa}=4$-(Aminomethyl)benzoic acid. 


\section{6. ${ }^{68}$ Ga-Labeled RGD Multimers}

An interesting alternative for the ${ }^{18} \mathrm{~F}$ and ${ }^{64} \mathrm{Cu}$ cyclotron-produced PET radionuclides is the generator-produced ${ }^{68} \mathrm{Ga}$, which can be eluted from an inhouse ${ }^{68} \mathrm{Ge} /{ }^{68} \mathrm{Ga}$ generator $\left({ }^{68} \mathrm{Ge}_{1} \mathrm{~T}_{1 / 2}=270.8\right.$ days $)$ and has optimal physical characteristics $\left(\beta^{+} 89 \%, 1.92 \mathrm{MeV}\right)$ for PET imaging. Furthermore, its half-life of $68 \mathrm{~min}$, is compatible with the pharmacokinetics of many peptides [31]. The following section refers to the ${ }^{68} \mathrm{Ga}$ radiolabeled $\mathrm{c}(\mathrm{RGD})$ multimers in comparison to their ${ }^{18} \mathrm{~F}$ and ${ }^{64} \mathrm{Cu}$ structural analogs, as well as to some ${ }^{68} \mathrm{Ga}$ radiolabeled $\mathrm{c}(\mathrm{RGD})$ multimers not previously mentioned.

Siitonen et al. prepared the $\left[{ }^{68} \mathrm{Ga}\right] \mathrm{Ga}-D O T A-E[c(R G D f K)]_{2} 23$ (Figure 8), which was then used for PET imaging of Shank-associated RH domain-interacting protein (SHARPIN)Regulated Integrin Activity in mice. [61] SHARPIN is a cytosolic protein that plays a key role in the activation of nuclear factor $\mathrm{K}$-light-chain enhancer of activated $\mathrm{B}$ cells and regulation of inflammation. Furthermore, SHARPIN controls integrin-dependent cell adhesion and migration in several normal and malignant cell types. Loss of SHARPIN correlates with increased integrin activity in mice. Increased integrin activity due to loss of SHARPIN protein would affect the uptake of the $\alpha_{\mathrm{v}} \beta_{3}$-selective 23 , both in several tissue types and in the tumor microenvironment. PET imaging in vivo was evaluated in wildtype $(w t)$ and SHARPIN-deficient mice (Sharpin ${ }^{\mathrm{cpdm}}$, where cpdm 5 designates chronic proliferative dermatitis in mice) with and without melanoma tumor allografts. Sharpin ${ }^{\text {cpdm }}$ mice with a spontaneous null mutation in the Sharpin gene and their wt littermates with or without B16-F10-luc melanoma tumors were studied using in vivo PET/CT imaging and ex vivo measurements with $\mathbf{2 3}$. The ex vivo uptake of $\mathbf{2 3}$ in the mouse skin and tumor was significantly higher in Sharpin ${ }^{\mathrm{cpdm}}$ mice than in wt mice, while B16-F10-luc tumors were detected $4 \mathrm{~d}$ after inoculation, without differences in volume or blood flow between the mouse strains. PET imaging even after 10 days of inoculation revealed significantly higher uptake in the tumors transplanted into Sharpin ${ }^{\mathrm{cpdm}}$ mice than in wt mice, while tumor vascularization was also increased in the Sharpin ${ }^{\mathrm{cpdm}}$ mice, indicating that SHARPIN may also have important regulatory roles in controlling the tumor microenvironment.

Liu et al. studied the two dimeric $c(R G D)$ pharmacophores $E\left[P^{2} G_{4}-c(R G D f K)\right]_{2}$ 35 and $\left.\mathrm{E}_{[} \mathrm{G}_{3}-\mathrm{c}(\mathrm{RGDfK})\right]_{2} 36$ linked with $\left[{ }^{68} \mathrm{Ga}\right] \mathrm{Ga}-\mathrm{NOTA}$ complex ( $p$-SCN-Bn-NOTA) (Figure 11) [62]. The ${ }^{68} \mathrm{Ga}$ analogs 35 or $\mathbf{3 6}$, contained the groups $\mathrm{PEG}_{4}$ and $\mathrm{G}_{3}$ linkers, respectively, only between the Glu scaffold and the c(RGD) pharmacophores, while in their $\left[{ }^{64} \mathrm{Cu}\right] \mathrm{Cu}-\mathrm{DOTA}$ analogs 31, 32 (Figure 9) [58] a $\mathrm{PEG}_{4}$ or $\mathrm{G}_{3}$ linker is additionally included between the chelator group and the dimeric $c(R G D)$ ligands. The presence of the additional linker $\mathrm{PEG}_{4}$ or $\mathrm{G}_{3}$ in between the chelator group and the $\mathrm{c}(\mathrm{RGD})$ pharmacophores dramatically improved $\alpha_{\mathrm{v}} \beta_{3}$ integrin receptor avidity, i.e., NOTA-E[c(RGDfK) $]_{2}$ $\mathrm{IC}_{50}=100.04 \pm 2.85 \mathrm{nM}$, NOTA-E[PEG 4 -c (RGDfK) $]_{2} 35 \mathrm{IC}_{50}=33.96 \pm 2.17 \mathrm{nM}$, NOTA-

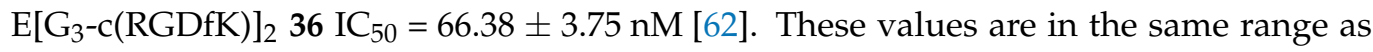
their DOTA analogs (32 $\left.\mathrm{IC}_{50}=62 \pm 6 \mathrm{nM}, 31 \mathrm{IC}_{50}=74 \pm 3 \mathrm{nM}\right)$, [58] indicating that the chelator did not significantly affect avidity. Instead, binding avidity was seriously affected by the applied spacer group. The benefits of using a $\mathrm{PEG}_{4}$ or $\mathrm{G}_{3}$ in the spacer were also observed in the biodistribution experiments, where it was shown that both radiotracers had higher (U87MG and MDA-MB-435) tumor uptake than the reference NOTA-E[cRGDfK) $]_{2}$ [63], while again, small differences were observed in comparison to their DOTA counterparts [58].

The imaging properties of the dimeric $c(R G D)$ and $c(N G R)$ radioligands $\left[{ }^{68} \mathrm{Ga}\right] \mathrm{Ga}$ NOTA-E[G ${ }_{3}-c($ RGDfK $\left.)\right]_{2} 36$ and $\left[{ }^{68} \mathrm{Ga}\right] \mathrm{Ga}-\mathrm{NOTA}-\mathrm{E}\left[\mathrm{G}_{3}-\mathrm{c}(\mathrm{CNGRC})\right]_{2} 37$, respectively, against angiogenesis were compared by Shao et al. [64] NGR peptides identified from a phage display are known to target the aminopeptidase $\mathrm{N}$ (APN/CD13) receptor, which has multiple functions associated with the progression of malignancy such as angiogenesis [65]. The two ligands presented similar pharmacokinetic profile, stability and tumor uptake (HT1080 fibrosarcoma) i.e., $60 \mathrm{~min}$ p.i., 36: $6.89 \pm 2.34 \% \mathrm{ID} / \mathrm{g}$; $37: 5.18 \pm 1.06 \% \mathrm{ID} / \mathrm{g}$ [64].

Li et al. also tested a dimeric $\left[{ }^{68} \mathrm{G}\right] \mathrm{Ga}-\mathrm{NOTA}-\mathrm{E}[\mathrm{c}(\mathrm{RGDyK})]_{2} 38$ and tetrameric $\left[{ }^{68} \mathrm{Ga}\right] \mathrm{Ga}-$ NOTA-E $\left\{E[c(R G D y K)]_{2}\right\}_{2} 39$ analogue of $c(R G D)$ for integrin $\alpha_{v} \beta_{3}$ targeting [66]. The 
tetramer 39 was proved superior in vitro in U87MG cells, $39 \mathrm{IC}_{50}=16.1 \pm 3.1 \mathrm{nM}>38$ $\mathrm{IC}_{50}=60.1 \pm 7.6 \mathrm{nM}>$ monomer $\mathrm{IC}_{50}=218 \pm 28 \mathrm{nM}$, while quantitative microPET imaging studies showed that it also had the highest tumor uptake but in combination with the highest kidney accumulation. Thus, the dimeric structure was again the most favorable choice of this study.

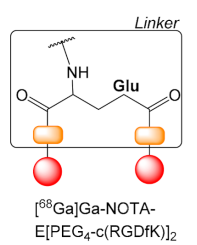

35
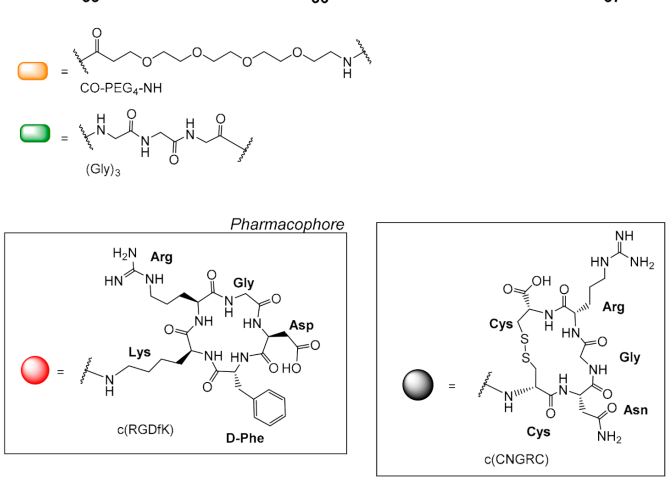

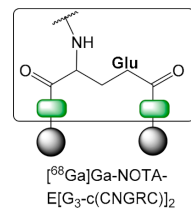

37

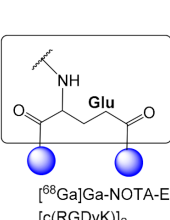

$[\mathrm{C}(\mathrm{RGDYK})]_{2}$
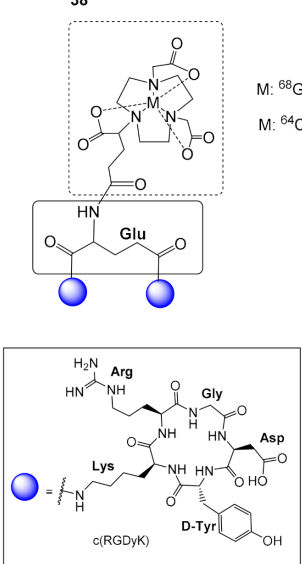

Figure 11. Chemical structures of the dimeric radioligands $\left[{ }^{68} \mathrm{Ga}\right] \mathrm{Ga}-\mathrm{NOTA}-\mathrm{E}\left[\mathrm{PEG}_{4}-\mathrm{c}(\mathrm{RGDfK})\right]_{2} 35$, $\left[{ }^{68} \mathrm{Ga}\right] \mathrm{Ga}-N O T A-E\left[G_{3}-\mathrm{c}(\mathrm{RGDfK})\right]_{2} 36$ and $\left[{ }^{68} \mathrm{Ga}\right] \mathrm{Ga}-\mathrm{NOTA}-\mathrm{E}\left[\mathrm{G}_{3}-\mathrm{c}(\mathrm{CNGRC})\right]_{2}$ 37, $\left[{ }^{68} \mathrm{Ga}\right] \mathrm{Ga}-\mathrm{NOTA}-$ $\mathrm{E}[\mathrm{c}(\mathrm{RGDyK})]_{2}$ 38, $\left[{ }^{68} \mathrm{Ga}\right] \mathrm{Ga}-\mathrm{NOTA}-\mathrm{E}\left\{\mathrm{E}[\mathrm{c}(\mathrm{RGDyK})]_{2}\right\}_{2} \mathbf{3 9},\left[{ }^{68} \mathrm{Ga}\right] \mathrm{Ga}-\mathrm{NODAGA}-\mathrm{E}[\mathrm{c}(\mathrm{RGDyK})]_{2} 40$ and $\left[{ }^{64} \mathrm{Cu}\right]$ Ga-NODAGA-E[c(RGDyK) $]_{2} 41$.

Oxboel et al. prepared the complexes of the dimeric pharmacophore NODAGA$\mathrm{E}[\mathrm{c}(\mathrm{RGDyK})]_{2}$ with ${ }^{68} \mathrm{Ga}$ and ${ }^{64} \mathrm{Cu}, 40$ and 41 respectively (NODAGA = 1,4,7triazacyclononane-1-glutaric acid-4,7-diacetic acid), to evaluate them as angiogenesis PET tracers (Figure 9). Radioligand [ $\left.{ }^{68} \mathrm{Ga}\right] \mathrm{Ga}-N O D A G A-E[c(R G D y K)]_{2}$ 40, $\left[{ }^{64} \mathrm{Cu}\right] \mathrm{Cu}-$ NODAGA-E[c(RGDyK) $]_{2} \mathbf{4 1}$ were tested in nude mice bearing either human glioblastoma (U87MG) or human neuroendocrine (H727) xenograft tumors [67]. PET/CT scans were conducted at selected time points and used for calculating the tracer uptake in tumors (\% ID/g) in parallel with biodistribution studies. Both tracers 40, 41 showed similar uptake in xenograft tumors 60 min after injection, U87MG, 40: $2.23 \pm 0.08 \%$ ID/g, 41: $2.31 \pm 0.15 \%$ ID/g; H727, 40: $1.53 \pm 0.06 \%$ ID/g vs. 41: $1.48 \pm 0.08 \%$ ID/g. Biodistribution studies showed similar tracer uptake for $\mathbf{4 0}$ and $\mathbf{4 1}$, however, $\mathbf{4 0}$ showed a slightly more stable tumor retention [67].

The cyclic peptide siderophore (FSC) (Figure 12), which has very good complexing properties for ${ }^{68} \mathrm{Ga}$ has been used as a scaffold for the synthesis of polymeric c(RGD) ligands [68]. Multimeric c(RGD) radioligands can be prepared either through the peptidic bond formation by coupling the $\mathrm{c}(\mathrm{RGD})$ peptide to the Fe-complex of the deacetylated form of Fusarinine-C (FSC) [68] or through a triazole ring formation using click CuAAC chemistry [23]. Subsequent Fe-demetallation (with $\mathrm{Na}_{2}$ EDTA) allows radiolabeling with ${ }^{68} \mathrm{Ga}$. 


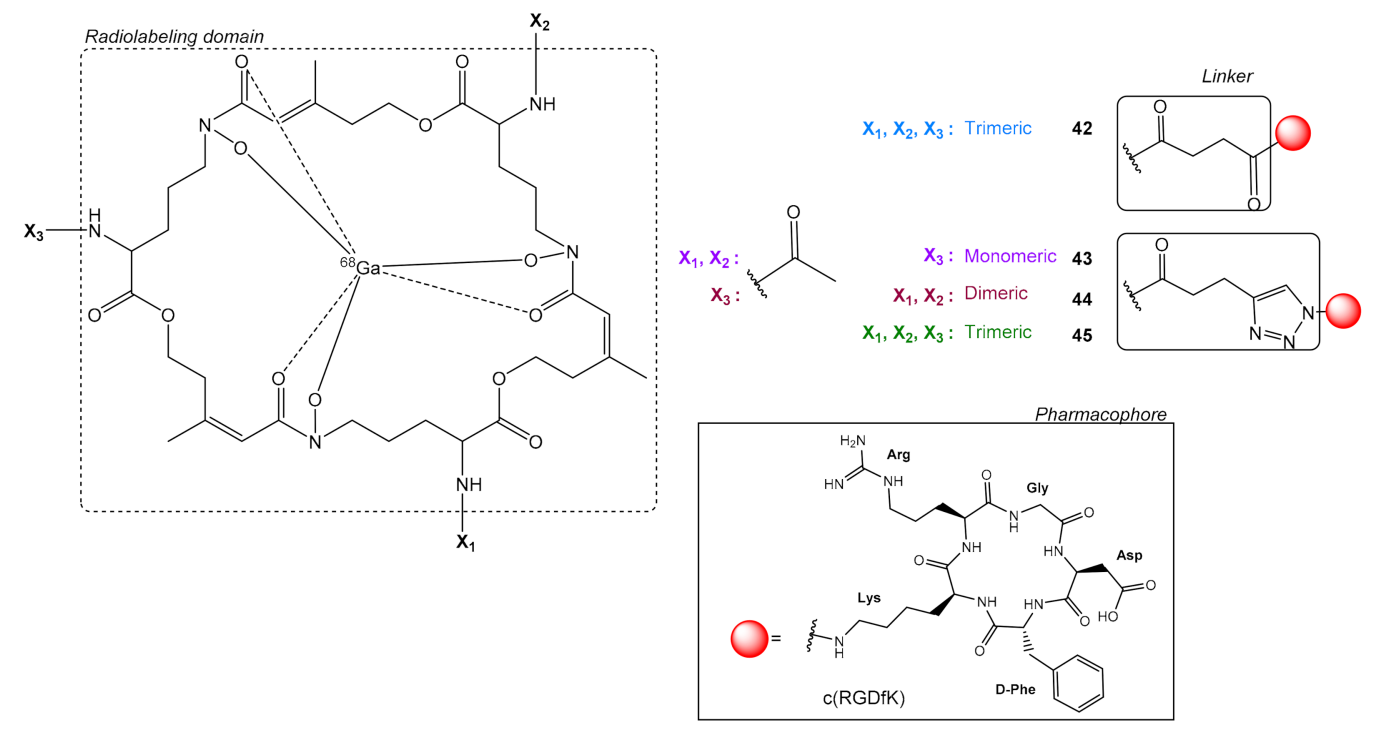

Figure 12. Chemical structures of conjugates between the natural chelator fusarinine $C$ (FSC) and c(RGDfK) pharmacophores, $\left[{ }^{68} \mathrm{Ga}\right] \mathrm{Ga}-\mathrm{FSC}-[\mathrm{E}-\mathrm{c}(\mathrm{RGDfK})]_{3}$ 42, $\left[{ }^{68} \mathrm{Ga}\right] \mathrm{Ga}-\mathrm{FSC}-\left(\mathrm{CH}_{2}\right)-\mathrm{Tz}-\mathrm{c}(\mathrm{RGDfK}) 43,\left[{ }^{68} \mathrm{Ga}\right] \mathrm{Ga}-\mathrm{FSC}-\left[\left(\mathrm{CH}_{2}\right)-\mathrm{Tz}-\mathrm{c}(\mathrm{RGDfK})\right]_{2}$ 44, $\left[{ }^{68} \mathrm{Ga}\right] \mathrm{Ga}-$ FSC-[( $\left.\left.\mathrm{CH}_{2}\right)-\mathrm{Tz}-\mathrm{c}(\mathrm{RGDfK})\right]_{3} 45$.

In this context, Knetsch et al. [68] prepared the trimeric c(RGD) peptide $\left[{ }^{68} \mathrm{Ga}\right.$ Ga-FSC$[\mathrm{E}-\mathrm{c}(\mathrm{RGDfK})]_{3} 42$ and tested it in vitro in $\alpha_{\mathrm{v}} \beta_{3}$ positive human melanoma M21 cells (vs. control integrin negative M21-L) [68]. Ligand 42 showed high avidity $\left(\mathrm{IC}_{50}=1.8 \pm 0.6 \mathrm{nM}\right)$ and receptor-specific internalization, while in vivo it showed specific tumor uptake (60 min p.i., M21: $4.25 \pm 0.64 \%$ ID/g, M21-L: $1.13 \pm 0.38 \%$ ID/g) with good contrast ratios i.e., tumor $/$ blood $=8.2$, tumor $/$ muscle $=7.4$. The reference monomer $\left[{ }^{68} \mathrm{Ga}\right] \mathrm{Ga}-N O D A G A-$ $\mathrm{c}(\mathrm{RGD})$ on the other hand was inferior tumor/blood: 11.3 , tumor/muscle: 6.1 . Trimeric 42 was mainly excreted via the kidneys showing higher accumulation than the reference monomer, i.e., 60 min p.i. Kidneys: $4.7 \pm 0.5 \%$ ID/g vs $1.5 \%$ ID/g, respectively. However, only a one-time point was investigated (60 min p.i.) and not a complete kinetic analysis [68].

In a later study, Kaeopookum et al. prepared the monomeric, dimeric, and trimeric c(RGD) radioligands: [ $\left.{ }^{68} \mathrm{Ga}\right] \mathrm{Ga}-\mathrm{FSC}-\left(\mathrm{CH}_{2}\right)-\mathrm{Tz}-\mathrm{c}(\mathrm{RGDfK})$ 43, [ $\left.{ }^{68} \mathrm{Ga}\right] \mathrm{Ga}-\mathrm{FSC}-\left[\left(\mathrm{CH}_{2}\right)-\mathrm{Tz}-\right.$ $\mathrm{c}(\mathrm{RGDfK})]_{2} 44,\left[{ }^{68} \mathrm{Ga}\right] \mathrm{Ga}-\mathrm{FSC}-\left[\left(\mathrm{CH}_{2}\right)-\mathrm{Tz}-\mathrm{c}(\mathrm{RGDfK})\right]_{2} 45$, respectively. Their binding properties for integrin $\alpha_{v} \beta_{3}$ were evaluated in vitro as well as in vivo and compared with the monomeric [ [ $\left.{ }^{68} \mathrm{Ga}\right] \mathrm{Ga}-N O D A G A-c(R G D f K)$ and trimeric $\left[{ }^{68} \mathrm{Ga}\right] \mathrm{Ga}-F S C-[\mathrm{suc}-\mathrm{c}(\mathrm{RGDfK})]_{3}$ [23]. All ${ }^{68}$ Ga-labeled c(RGDfK) peptides displayed fair hydrophilicity ( $\log \mathrm{D}=-2.96$ to -3.80 ), low protein binding, and were stable in phosphate buffered-saline and serum up to $2 \mathrm{~h}$. In vitro receptor binding avidity and internalization assays in M21 cells showed specific uptake of all derivatives, which increased with the number of c(RGD) motifs i.e., $45>44$ $>43$. However, these in vitro avidity values did not exactly correspond with the in vivo (U87MG xenographs in mice) results, the monomer had the lowest tumor, but the dimer showed higher tumor uptake compared to the trimer i.e., $90 \mathrm{~min}$ p.i., $44: 8.19 \pm 0.41 \%$ ID/g > 45: $3.98 \pm 0.64 \%$ ID/g > 43: $2.73 \pm 0.28 \%$ ID/g, while tumor uptake for the reference trimeric $\left[{ }^{68} \mathrm{Ga}\right] \mathrm{Ga}-\mathrm{FSC}-(\mathrm{suc}-\mathrm{c}(\mathrm{RGDfK}))_{3}$ was $4.95 \pm 1.10 \% \mathrm{ID} / \mathrm{g}$. The dimeric 44 also showed the best tumor-to-background ratios. All radiolabeled compounds showed fast blood clearance and high accumulation in kidneys. The authors correlated the high tumor uptake of dimeric 44 compared to the trimeric 45 to the lower density of $\alpha_{v} \beta_{3}$-integrins on U87MG cells in comparison with the human melanoma M21 cells (preventing simultaneous binding) and this explanation was partly confirmed by the in vitro binding results [23].

A very interesting chelator group initially used by Notni et al. for c(RGDfK) multimerization is TRAP (1,4,7-triazacy-clononane-1,4,7-tris[(2-carboxyethyl)methylenephosphinic acid]) [69]. TRAP allows the efficient and high yielding complexation of ${ }^{68} \mathrm{Ga}^{3+}$, while presenting multiple sites for conjugation of pharmacophores. (Figure 13) Notni et al. did 
an extensive work testing various linkers i.e., $\mathrm{PEG}_{4}, \mathrm{PEG}_{8}$, Ahx (6-aminohexanoic acid), Glu, $-\mathrm{CH}_{2}-\mathrm{Tz}-\mathrm{Ahx}$, in between TRAP and $\mathrm{c}$ (RGDfK) to conclude in the choice of $\mathrm{PEG}_{4}$ and ligand 46, which showed the higher avidity for integrin $\alpha_{\mathrm{V}} \beta_{3}$ (M21/negative M21-L). 46 showed in vitro a 7-fold higher avidity compared to the monomers F-Galacto-RGD and Ga-NODAGA-c(RGDyK), and in vivo high tumor uptake (60 min p.i., $6.08 \pm 0.63 \%$ ID/g), was and fast renal clearance.

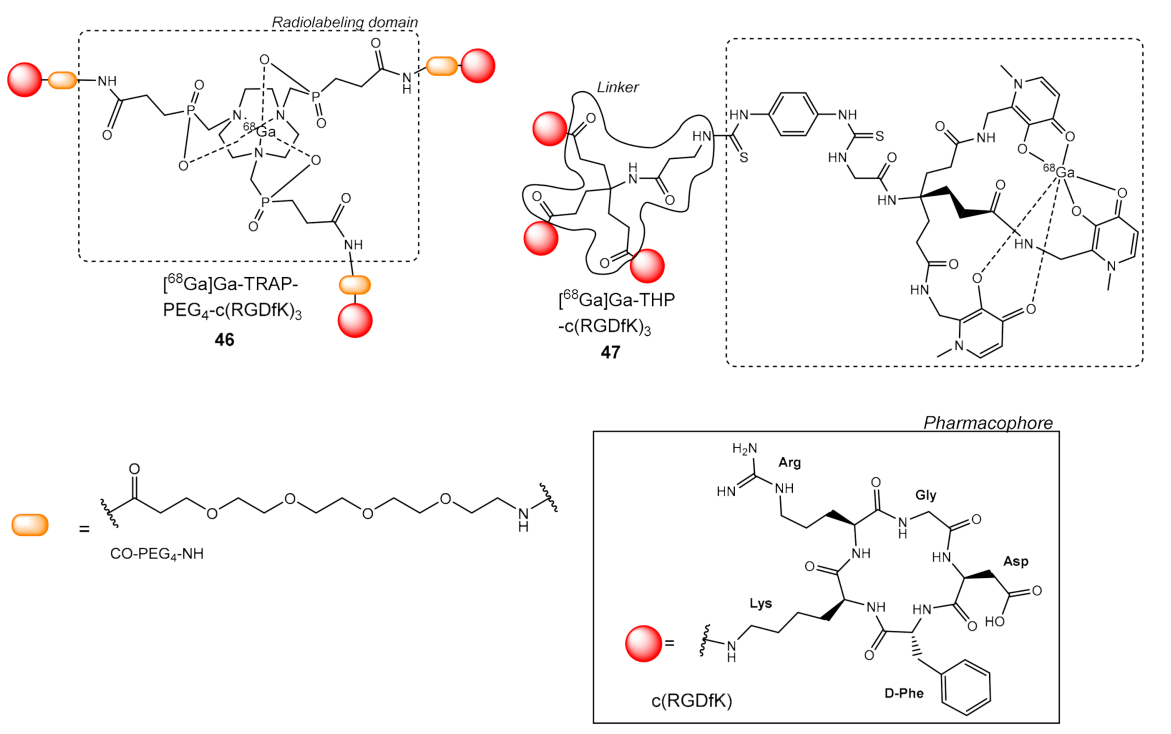

Figure 13. Chemical structures of ${ }^{68} \mathrm{Ga}$ trimers of c(RGDfK) with TRAP 46 and THP 47 chelator groups.

In a study by Lobeek et al., they compared dimeric 24 and trimeric c(RGDfK) ligands 42,46 , and 47, which contains a bifunctional tris(hydroxypyridinone) chelator THP $\left(\mathrm{H}_{3} \mathrm{THP}-\mathrm{Ph}-\mathrm{NCS}\right)$ (Figure 13). During the in vitro experiments, the dimeric ligand 24 was superior; presenting the lowest $\mathrm{IC}_{50}$ value $(3.8 \pm 0.7 \mathrm{nM})$, while $\mathrm{IC}_{50}$ values of the trimeric structures did not significantly differ (9.0-11.4 nM). The FSC analog 42 presented the highest tumor uptake in the SK-RC- 52 (human renal cell carcinoma) model (60 min p.i. $12.5 \pm 2.5 \% \mathrm{ID} / \mathrm{g}$ ), while the rest of the ligands had lower values (all in the $4.4-5.3 \% \mathrm{ID} / \mathrm{g}$ ). In the FaDu model (human squamous cell carcinoma, tumor cells expressing $\alpha_{\mathrm{v}} \beta_{3}$ integrin solely on the neovasculature; $\alpha_{\mathrm{v}} \beta_{3}$ integrin-negative tumors), 42 was significantly higher (60 min p.i. $1.9 \pm 0.3 \% \mathrm{ID} / \mathrm{g}$ ) than that of $46(1.0 \pm 0.2 \% \mathrm{ID} / \mathrm{g})$, but it did not significantly differ from the other two ligands $24(1.6 \pm 0.5 \% \mathrm{ID} / \mathrm{g})$ or $47(2.2 \pm 0.7 \% \mathrm{ID} / \mathrm{g})$. The optimal choice according to the authors were the trimeric structures 42 and 47 [70].

The studies so far have shown that there is no significant advantage in using radiolabeled tetramers: $E\left\{E[c(R G D-X-K)]_{2}\right\}_{2}\left(X=f\right.$ or y) over their dimeric analogs: $E[c(R G D-X-K)]_{2}$ $(\mathrm{X}=\mathrm{f}$ and $\mathrm{y})$, regarding tumor to background $(\mathrm{T} / \mathrm{B})$ ratios or normal organ uptake. It seems that there is a limit on the benefits provided by the increasing pharmacophore multiplicity since over two c(RGD) pharmacophores increased the uptake in normal organs (kidneys, liver, lungs, and spleen). In addition, multiplicity increases production complexity and costs; two factors, which act prohibitively for the future development of multimers c(RGD) with $n>4$, as integrin $\alpha_{\mathrm{v}} \beta_{3}$-targeting radiotracers [20].

\subsection{Clinically Applied RGD Multimers}

A number of multimeric integrin-targeting $\mathrm{c}(\mathrm{RGD})$ radioligands have been applied since 2014 for prospective human studies, mainly focusing on oncological diseases (Table 1) $[24,25,71]$. Ligand $\left[{ }^{18} \mathrm{~F}\right] \mathrm{FP}-\mathrm{PRGD}_{2} 8$ was the first dimeric $\mathrm{c}(\mathrm{RGD})$ tracer that was clinically applied in healthy volunteers. Mitra et al. showed that this tracer had good tolerance as well as favorable biodistribution and dosimetric characteristics [72], leading to its FDA approval as an exploratory investigative new drug (IND 104150) in human subjects. 
Iagaru et al. reported that in a pilot evaluation of radioligand 8, eight women with newly diagnosed or recurrent breast cancer (BCa) underwent PET/CT with 8 and the commonly used radiopharmaceutical in PET imaging $\left[{ }^{18} \mathrm{~F}\right] \mathrm{FDG}$ [73]. The radioligand 8 showed high and specific uptake in primary cancer, as well as in the metastatic lesions, with no safety issues reported or measured. The biodistribution of 8 in cancer patients was extensively investigated in a later study by Minamimoto et al. reporting high tracer accumulation in the bladder and kidneys, due to the tracer's predominant renal clearance, followed by the choroid plexus, spleen, salivary glands, thyroid, liver, pancreas, and bowel [74]. The above results in addition to the observed good tumor-to-background ratios suggested the ligand's $\mathbf{8}$ suitability for further clinical use. Furthermore, the dimeric c(RGD) 8 was found clinically superior to the monomers $\left[{ }^{18} \mathrm{~F}\right] \mathrm{FP}$-galacto-E(c(RGDfK) $]\left(\left[{ }^{18} \mathrm{~F}\right] \mathrm{FP}\right.$-galacto-RGD) and $\left[{ }^{18} \mathrm{~F}\right] \mathrm{FP}-\mathrm{E}-\mathrm{c}(\mathrm{RGDfK})\left(\left[{ }^{18} \mathrm{~F}\right]\right.$ Fluciclatide) $[24,75]$, which was in accordance with the preclinical animal studies [48]. Additionally, the lack of significant correlation between tumor uptake for 8 and $\left[{ }^{18} \mathrm{~F}\right] \mathrm{FDG}$ confirmed that the two PET tracers provide different molecular information [74].

Table 1. Clinical studies with multimeric c(RGD) molecules.

\begin{tabular}{|c|c|c|c|c|c|}
\hline Imaging Agent & Year & \# Patients & Confirmation & Neoplasm & Ref. \\
\hline $\begin{array}{c}\left.{ }^{18} \mathrm{~F}\right] \mathrm{FP}-\mathrm{PRGD} \\
\mathbf{8}\end{array}$ & 2014 & 8 & $\mathrm{HP}$ & $\mathrm{BCa}$ & [73] \\
\hline $\begin{array}{c}{\left[{ }^{18} \mathrm{~F}\right] \text { Alfatide I }} \\
\mathbf{1 0}\end{array}$ & 2015 & $26 / 16$ & $\mathrm{HP}$ & LCa/Lnd & [76] \\
\hline $\begin{array}{c}{\left[{ }^{18} \text { F }\right] \text { Alfatide I PET } / \mathrm{CT}} \\
\mathbf{1 0}\end{array}$ & 2017 & 13 & $\mathrm{HP}$ & Lnd & [77] \\
\hline $\begin{array}{c}{\left[{ }^{18} \mathrm{~F}\right] \text { Alfatide II PET } / \mathrm{CT}} \\
\mathbf{1 4}\end{array}$ & 2015 & $\begin{array}{c}5(\mathrm{HV}) \\
9\end{array}$ & $\mathrm{MRI} / \mathrm{CT}$ & $\mathrm{BrCa}$ & [54] \\
\hline $\begin{array}{l}{\left[{ }^{18} \text { F }\right] \text { Alfatide II PET } / \mathrm{CT}} \\
\mathbf{1 4}\end{array}$ & 2015 & 30 & & $\mathrm{BnCa}$ & [53] \\
\hline $\begin{array}{c}{\left[{ }^{18} \mathrm{~F}\right] \text { Alfatide II PET } / \mathrm{CT}} \\
\mathbf{1 4}\end{array}$ & 2018 & 44 & $\mathrm{HP}$ & $\mathrm{BCa}$ & [52] \\
\hline $\begin{array}{c}{\left[{ }^{68} \mathrm{Ga}\right] \mathrm{Ga}-\mathrm{NOTA}-\mathrm{PRGD}_{2} \text { PET } / \mathrm{CT}} \\
\mathbf{1 2}\end{array}$ & 2015 & $\begin{array}{c}91 \\
159\end{array}$ & $\mathrm{HP}$ & Lnd & [78] \\
\hline $\begin{array}{c}{\left[{ }^{68} \mathrm{Ga}\right] \mathrm{Ga}-\mathrm{RGD}_{2} \mathrm{PET} / \mathrm{CT}} \\
\mathbf{1 5}\end{array}$ & 2017 & $31(21 / 10)$ & $\mathrm{HP}$ & NSCLC/SCLC & [79] \\
\hline $\begin{array}{c}{\left[{ }^{68} \mathrm{Ga}\right] \mathrm{Ga}-\mathrm{RGD}_{2} \mathrm{PET} / \mathrm{CT}} \\
\mathbf{1 5}\end{array}$ & 2016 & $21 / 13$ & $\mathrm{HP}$ & NSCLC/TB & [51] \\
\hline
\end{tabular}

Abbreviations used: HP: Histopathology; Lnd: Lymph nodes; BCa: breast cancer; LCa: lung cancer; BrCa: Brain cancer; BnCa: Bone Cancer; NSCLC: non-small cell lung cancer; SCLC: small cell lung cancer; TB: tuberculosis.

In a clinical study investigating 10 's feasibility for lung cancer detection, 26 patients with suspected lung cancer underwent PET/CT with this tracer before surgery and puncture biopsy. Standardized uptake values (SUVs) and tumor-to-blood ratios were measured, and diagnoses were also pathologically confirmed. Results showed that $\mathbf{1 0}$ was able to clearly identify all primary lesions with desirable image contrast (sensitivity $=100 \%$, specificity $=44 \%$, accuracy $=81 \%$, positive predictive value $[\mathrm{PPV}]=77 \%$ and negative predictive value $[\mathrm{NPV}]=100 \%$ ). The SUV for malignant lesions was significantly higher than that for hamartomas. However, it was difficult to clearly differentiate inflammatory or inflammatory pseudotumors from malignant lesions [76].

In another study of 10, 13 patients with non-small cell lung cancer (NSCLC) underwent PET/CT before surgery [77]. All malignant lymph nodes (LNs) were successfully visualized with a sensitivity of $100 \%$, a specificity of $95 \%$, and an accuracy of $95 \%$. SUVmax, SUVmean, and SUV ratios in malignant LNs were significantly higher than in benign LNs. Similar results were observed in patients with adenocarcinoma and squamous cell 
carcinoma. Tracer 10 showed high sensitivity (83.9-100\%), specificity (78.6-96.7\%), and accuracy (81.7-96.9\%) according to thresholds calculated from receiver operating characteristic curves.

Hitherto, the majority of clinical studies regarding $c($ RGD) multimers have been conducted for tracer $\left.{ }^{18} \mathrm{~F}\right]$ Alfatide II 14 [52-54]. The radiotracer was initially (2015) investigated in five healthy volunteers and nine patients with brain metastases (identified by MRI and/or CT) originating from various primary tumors i.e., lung, ovarian, gastric [54]. 14 was well tolerated without any serious tracer-related adverse events. The tracer showed rapid clearance from the blood pool and kidneys, while the organs with the highest absorbed dose were the kidneys and the spleen. Further, the detection rate of $\mathbf{1 4}$ was compared to other imaging modalities, in particular, CT and $\left[{ }^{18} \mathrm{~F}\right] \mathrm{FDG}$ PET/CT. The comparison revealed that all 20 brain lesions were visualized by 14, while 13/20 lesions were visualized by CT and only $10 / 20$ by $\left[{ }^{18}\right.$ F]FDG PET/CT [54]. Of note, however, is the fact that $\left[{ }^{18} \mathrm{~F}\right]$ FDG is not an optimal imaging biomarker for brain tumors; instead, amino acid PET tracers, such as L-[methyl- $\left.{ }^{11} \mathrm{C}\right]$ methionine $\left({ }^{11} \mathrm{C}-\mathrm{MET}\right), \mathrm{O}-\left(2-\left[{ }^{18} \mathrm{~F}\right]\right.$ fluoroethyl $)$-L-tyrosine $\left(\left[{ }^{18} \mathrm{~F}\right] \mathrm{FET}\right)$, and 3,4-dihydroxy-6-[ $\left[{ }^{18} \mathrm{~F}\right]$ Fluoro-L-phenylalanine ([$\left.\left.{ }^{18} \mathrm{~F}\right] \mathrm{FDOPA}\right)$, yield better results regarding brain tumors' detection [80,81]. 14 was also investigated for the diagnosis of bone cancer metastasis (2015) in 11 patients ( $n=7$ lung cancer, $n=2$ cancer of unknown primary site, $n=1$ gastric cancer, $n=1$ urinary bladder cancer associated with gastric cancer) who underwent PET/CT with [ $\left.{ }^{18} \mathrm{~F}\right] \mathrm{FDG}$ and 14 [53]. The final diagnosis of bone lesions was established based on the comprehensive assessment of all available data and clinical follow-up. Bone metastases were divided into four groups: osteolytic, osteoblastic, mixed, and bone marrow. PET/CT imaging using 14 detected the bone metastatic lesions with good contrast and higher sensitivity (positive rate of $92 \%$ ) than $\left[{ }^{18} \mathrm{~F}\right] \mathrm{FDG}$ (77\%), especially in detecting osteoblastic (70\% vs. $53 \%$ ) and bone marrow metastatic lesions (98\% vs. $77 \%$ ). PET/CT sensitivity of 14 in osteolytic metastasis was $100 \%$, while for $\left[{ }^{18} \mathrm{~F}\right]$ FDG was $90 \%$ [53]. Moreover, 14 was compared to $\left[{ }^{18} \mathrm{~F}\right]$ FDG for detecting BCa, in a cohort of 44 female patients [52]. PET/CT image analysis was based on visual and semi-quantitative analysis ( $\left.\mathrm{SUV}_{\max }, \mathrm{SUV}_{\text {mean }}\right)$. In total, $42 \mathrm{BCa}$ lesions and 11 benign breast lesions were confirmed by histopathology. Both 14 and $\left[{ }^{18} \mathrm{~F}\right] \mathrm{FDG}$ showed higher uptake for $\mathrm{BCa}$ lesions than benign ones $(p<0.05)$ with 14 showing less uptake and area under the curve than $\left[{ }^{18} \mathrm{~F}\right]$ FDG. Both 14 and $\left[{ }^{18} \mathrm{~F}\right]$ FDG had high sensitivity $(88.1 \%$ vs. $90.5 \%)$, high positive predictive value (PPV $88.1 \%$ vs. $88.4 \%$ ), moderate specificity ( $54.5 \%$ vs. $54.5 \%$ ), and moderate negative predictive value (NPV 54.5\% vs. $60.0 \%$ ) for differentiating BCa from benign breast lesions. Overall, 14 showed a diagnostic value comparable to that of $\left[{ }^{18} \mathrm{~F}\right]$ FDG but was not superior in the identification of BCa. The combination of $\mathbf{1 4}$ and $\left[{ }^{18} \mathrm{~F}\right] \mathrm{FDG}$, increased sensitivity to $97.6 \%$ and NPV to $85.7 \%$, while the PPV was slightly increased to $89.1 \%$, without any change in specificity (54.5\%) [52].

Additionally, when this ligand NOTA-E[PEG 4 -c(RGDfK) $]_{2}$ was labeled with ${ }^{68} \mathrm{Ga}, 15$ $\left(\left[{ }^{68} \mathrm{Ga}\right] \mathrm{Ga}-\mathrm{RGD}_{2}\right)$ was compared to $\left[{ }^{18} \mathrm{~F}\right] \mathrm{FDG}$ in LCa patients. [79] Thirty-one patients with pathologically confirmed tumors were enrolled, (21 NSCLC, and 10 small cell lung, SCLC). PET/CT images were acquired using 15 and $\left[{ }^{18} \mathrm{~F}\right]$ FDG. The SUVs for $\left[{ }^{18} \mathrm{~F}\right] \mathrm{FDG}\left(\mathrm{SUV}_{\max }\right.$, $\mathrm{SUV}_{\text {mean }}$ ) were not significantly different between NSCLC and SCLC patients. On the contrary, 15 uptake of SCLC patients was at background levels and significantly lower than that of NSCLC patients, indicating lower $\alpha_{v} \beta_{3}$ targeting level for C(RGD) in SCLC. The dimeric ligand 15, could not only detect but also differentiating NSCLC and SCLC cases while detecting intra-tumor heterogeneities [79]. Tracer 15 was also used for differentiating NSCL and tuberculosis (21 NSCLC patients and 13 TB patients were recruited). The values noted for 15 regarding $S U V_{\text {max }}$ and $S U V_{\text {mean }}$ and area under the curve were significantly different between NSCLC and TB, while the visual differentiation diagnostic specificity of 15 was higher than that of $\left[{ }^{18}\right.$ F]FDG $(84.62 \%$ vs. $53.85 \%)$, with one-third of false-positive rate $(15.4 \% / 46.2 \%)$ over the $\left[{ }^{18} \mathrm{~F}\right] \mathrm{FDG}$ rate. In addition, for the detection of NSCLC lymph nodes, 15 showed superior specificity (100\% vs. 66.7\%), [ ${ }^{18}$ F]FDG (87.5\% vs. 75\%) [51]. 
The dimeric structure 12 (Figure 3) was investigated in comparison to $\left[{ }^{18} \mathrm{~F}\right] \mathrm{FDG}$ in 91 LCa patients [78]. Tracer 12 was well tolerated, while it rapidly cleared from the blood pool, mainly through the urinary system. The SUVs for proven malignancies were significantly higher than benign lesions with 12 showing a sensitivity of $84 \%$, specificity of $91 \%$, and accuracy of $86 \%$, exhibiting a diagnostic value comparable to $\left[{ }^{18} \mathrm{~F}\right] \mathrm{FDG}$ for LCa detection. Moreover, 12 was more specific than $\left[{ }^{18} \mathrm{~F}\right] \mathrm{FDG}$ PET/CT in assessing LN metastasis, with PPV of $90 \%$ (30\% for $\left.\left[{ }^{18} \mathrm{~F}\right] \mathrm{FDG}\right)$ and NPV and $94 \%$ (91\% for $\left.\left[{ }^{18} \mathrm{~F}\right] \mathrm{FDG}\right)$, respectively [78].

Although being structurally different, all the clinically investigated RGD peptides, including monomers and dimers, depict very similar in vivo pharmacokinetic properties [24]. Regarding 8, and 14, the two most clinically studied dimers, they were able to detect integrin-positive tumors with good imaging contrast, while showing comparable imaging properties and pharmacokinetics, and while exhibiting high sensitivity (for primary lesions $83.3-100 \%$ and for metastatic lesions $70-100 \%$ ) and specificity for tumor detection and staging. Besides the urogenital system, moderate to prominent off-target uptake was observed for both in the liver, which can be an issue for detecting hepatic tumors or metastases [43,52,82].

Until recently, only a small number of clinical investigations of dimeric RGD peptides have been reported, and the sensitivity/specificity between dimers and monomers has not been compared in the same patients. Thus, additional evaluation with large cohorts is needed to determine if the multimeric strategy provides higher sensitivity and specificity for tumor detection and staging than the monomeric RGD compounds and the golden standard $\left[{ }^{18} \mathrm{~F}\right] \mathrm{FDG}[24]$.

\section{Discussion}

Multimeric PET radioligands consist of identical binding motifs (pharmacophores) connected to a single backbone (linker) attached to a group, which can be labeled with a positron-emitting radionuclide suitable for PET molecular imaging (radiolabeled domain). Among the various PET multimeric radioligands investigated for targets like integrin $\alpha_{\mathrm{V}} \beta_{3}$, PSMA, GRPr, VEGFR, and EGFR-TKI, the ones targeting integrin $\alpha_{\mathrm{V}} \beta_{3}$ are the most studied and the only category which has reached the clinical stage of development (Table 1). Multimeric c(RGD) analogs are a fine example, providing proof that multimerization can improve ligands characteristics like receptor avidity and tumor uptake.

Several factors regarding the design of $\mathrm{c}(\mathrm{RGD})$ multimeric radioligands should be taken under consideration. One of the most important factors is the length and flexibility of the linker (1) connecting the chelator group with the multimeric scaffold and (2) connecting the various pharmacophores. Regarding the first case of linker (1), several examples of ${ }^{18}$ F-labeled compounds, 7-10 (Figure 3) have shown that the introduction of PEG group in-between the pharmacophores and the labeling site not only improves the overall radiolabeling yield but also reduces the renal uptake and increases tumor-targeting efficacy [36]. Specifically, the introduction of $\mathrm{PEG}_{3}$ minimized the instability factors observed in the acidic and high-temperature radiolabeling conditions of 10, due to the thiourea linkage of the labeling site with the $\alpha$-amine of the Glu linker [50]. Considering the second case (2), the length of the linker defines the distance between the two pharmacophores. Cyclic RGD dimeric peptides, where the Glu linker was connected with each c(RGD) using additional groups like $\mathrm{PEG}_{4}$ or $\mathrm{G}_{3}$ e.g., 14-16 (Figure 4) or 29-32 (Figure 9) have shown better results, with respect to tumor uptake, than other ligands with shorter linkers [20]. In particular, for $c$ (RGD) dimers, it seems that this distance has to be in the range of 30-38 bonds like in 26, 27 [30] or the SAR conjugate $33[57,58]$ for achieving bivalency, and eventually leading to higher integrin $\alpha_{\mathrm{v}} \beta_{3}$ binding avidity [20].

Several pharmacodynamic models have been proposed as an explanation for the observed improvements in binding avidity, reduced receptor off-rate, which eventually result in high tumor uptake. One of the models suggests simultaneous binding of the ligand with two receptors on the cell surface; this can be accomplished with the utilization 
of extremely long spacers, which cover the distance between two receptors on the cell surface. However, extremely long spacers do not always prove to be advantageous for the pharmacodynamic or pharmacokinetic ligand characteristics, because they may prevent other actions such as the internalization of the ligand or may worsen its pharmacokinetic properties, resulting in reduced tumor uptake. Another model describing the improved effects observed for multimeric ligands is based on the improved statistical effect, in this case, the ligand binds to one receptor, but its apparent local concentration of the ligand in proximity to the receptors is increased. This seems to be the most likely explanation for ligands with short linkers [1].

Another factor regarding the design of $c(R G D)$ multimers is the number of $c(R G D)$ pharmacophores included. Increasing the number of pharmacophores had a positive effect on ligand avidity and cell binding in vitro. Nevertheless, this effect did not always correspond with similar advantages in vivo, since increasing peptide multiplicity, in many cases resulted in a parallel increase of ligand uptake in normal organs. Thus, the benefits of multiplicity seem to have limits. Among the multimers summarized in this article, the dimers seem the most successful cases and that is also the reason they have further advanced in the clinic, over the other tracers.

Several examples of $c$ (RGD) multimers for PET imaging of integrin $\alpha_{v} \beta_{3}$ have been studied so far, which have been labeled with various PET radionuclides i.e., ${ }^{18} \mathrm{~F},{ }^{68} \mathrm{Ga}$, and ${ }^{64} \mathrm{Cu}$ (for a list of compounds included in the article along with the $\alpha_{\mathrm{v}} \beta_{3}$ expressing cells/tumor models tested refer to Table 2 ). The ${ }^{18} \mathrm{~F}$ analogs and specifically dimeric $\left[{ }^{18} \mathrm{~F}\right] \mathrm{F}$ $c(R G D)_{2}$ ligands have been the most successful and have already reached the stage of clinical development for various applications utilizing integrin $\alpha_{\mathrm{V}} \beta_{3}$ imaging like cancer (ligands 8, 10, and 14). However, the NOTA analogs, which are labeled using $\left[{ }^{18} \mathrm{~F}\right] \mathrm{AlF}$, a much easier, faster, and high yielding production procedure (40 min and $20 \mathrm{~min}$ for kit radiolabeling, yield $42 \%$, radiochemical purity $>95 \%$ ), have significant advantages for their future clinical application, especially after the introduction of kit formulations. Among the two compounds developed so far: $\left[{ }^{18} \mathrm{~F}\right]$ Alfatide I 10 and $\left[{ }^{18} \mathrm{~F}\right]$ Alfatide II 14; the second is considered more stable regarding a possible intermolecular Lewis acid-catalyzed hydrolysis during its production. Besides ${ }^{18} \mathrm{~F}$, another popular positron-emitting radioisotope is ${ }^{68} \mathrm{Ga}$, which can be produced by a ${ }^{68} \mathrm{Ge} /{ }^{68} \mathrm{Ga}$ generator. So far one clinical study has been published for each of the ${ }^{68} \mathrm{Ga}$ labeled dimeric structures, 12 and 15 . Tracer 12 showed similar pharmacokinetics with 10 , which can also be labeled with ${ }^{68} \mathrm{Ga}$, and is of alike chemical structure to 14. Consequently, additional results of clinical studies regarding $\left[{ }^{68} \mathrm{Ga}\right] \mathrm{Ga}-\mathrm{c}(\mathrm{RGD})_{2}$ dimers i.e., $\mathbf{1 2}$ or $\mathbf{1 5}$ are expected to be published in the near future.

Table 2. List of $\mathrm{c}(\mathrm{RGD})$ multimeric radioligands $\alpha_{\mathrm{v}} \beta_{3}$-integrin cell and tumor models tested.

\begin{tabular}{|c|c|c|c|c|}
\hline \# & Name & Cell \& Tumor Model & Ref. & Figure \\
\hline 1 & {$\left[{ }^{18} \mathrm{~F}\right] \mathrm{FBOA}-\mathrm{Dpr}-\mathrm{HEG}-\mathrm{c}(\mathrm{RGDfE})$} & \multirow{3}{*}{$\begin{array}{l}\text { M21 Human melanoma } \\
\text { U87MG human glioblastoma }\end{array}$} & \multirow{3}{*}[22,33]{} & \multirow{3}{*}{ Figure 2} \\
\hline 2 & {$\left[{ }^{18} \mathrm{~F}\right] \mathrm{FBOA}-\mathrm{Dpr}-\mathrm{K}(\mathrm{HEG}-\mathrm{c}(\mathrm{RGDfE}))_{2}$} & & & \\
\hline 3 & {$\left[{ }^{18} \text { F]FBOA-Dpr-K }\{\text { K[HEG-(c(RGDfE) }]_{2}\right\}_{2}$} & & & \\
\hline 4 & {$\left[{ }^{18} \mathrm{~F}\right] \mathrm{FB}-\mathrm{E}[\mathrm{c}(\mathrm{RGDyK})]_{2}$} & $\begin{array}{l}\text { HBCECs human brain capillary } \\
\text { endothelial cells, U87MG }\end{array}$ & \multirow[b]{2}{*}[34,35]{} & \multirow{5}{*}{ Figure 3} \\
\hline 5 & $\begin{array}{c}\left.{ }^{18} \mathrm{~F}\right] \mathrm{FP}-\mathrm{E}[\mathrm{c}(\mathrm{RGDyK})]_{2} \\
{ }^{18} \mathrm{~F}-\mathrm{FP}-\mathrm{RGD}_{2}\end{array}$ & U87MG & & \\
\hline 6 & $\begin{array}{c}{\left[{ }^{18} \mathrm{~F}\right] \mathrm{AlF}-\mathrm{NOTA}-\mathrm{E}[\mathrm{c}(\mathrm{RGDyK})]_{2}} \\
{\left[{ }^{18} \mathrm{~F}\right] \mathrm{AlF}-\mathrm{NOTA}-\mathrm{RGD}_{2}}\end{array}$ & U87MG & {$[35,46]$} & \\
\hline 7 & $\begin{array}{c}{\left[{ }^{18} \mathrm{~F}\right] \mathrm{FB}-\mathrm{PEG} \mathrm{E}_{3}-\mathrm{E}\left[\mathrm{c}(\mathrm{RGDHK}]_{2}\right.} \\
{\left[{ }^{18} \mathrm{~F}\right] \mathrm{FB}-\mathrm{PRGD}} \\
\end{array}$ & U87MG & {$[36,37]$} & \\
\hline 8 & $\begin{array}{c}{\left[{ }^{18} \mathrm{~F}\right] \mathrm{FP}-\mathrm{PEG} \mathrm{E}_{3}-\mathrm{E}[\mathrm{c}(\mathrm{RGDyK})]_{2}} \\
{\left[{ }^{18} \mathrm{~F}\right] \mathrm{FP}-\mathrm{PRGD}{ }_{2}}\end{array}$ & HCT116 human colon cancer, U87MG & {$[27,39,72-74]$} & \\
\hline
\end{tabular}


Table 2. Cont.

\begin{tabular}{|c|c|c|c|c|}
\hline$\#$ & Name & Cell \& Tumor Model & Ref. & Figure \\
\hline 9 & {$\left[{ }^{68} \mathrm{Ga}\right] \mathrm{Ga}-\mathrm{NOTA}-\mathrm{PEG}_{3}-\mathrm{E}[\mathrm{c}(\mathrm{RGDyK})]_{2}$} & U87MG & {$[38,39]$} & \\
\hline 10 & $\begin{array}{c}{\left[{ }^{18} \mathrm{~F}\right] \text { AlF-NOTA-PEG }} \\
\text {-E }[\mathrm{c}(\mathrm{RGDyK})]_{2} \\
{\left[{ }^{18} \mathrm{~F}\right] \text { Alfatide I }}\end{array}$ & $\begin{array}{c}\text { U87MG, A549 adenocarcinomic human } \\
\text { alveolar basal epithelial cells, PC-3 } \\
\text { prostate cancer, LLC Lewis Lung } \\
\text { Carcinoma }\end{array}$ & {$[38-41,76,77]$} & \\
\hline 11 & $\begin{array}{c}{\left[{ }^{18} \mathrm{~F}\right] \mathrm{FP}-\mathrm{PEG}_{4}-\mathrm{E}[\mathrm{c}(\mathrm{RGDfK})]_{2}} \\
{\left[{ }^{18} \mathrm{~F}\right] \mathrm{FP}-\mathrm{PRGD}} \\
\end{array}$ & U87MG, MDA-MB-435 & [45] & \multirow{6}{*}{ Figure 4} \\
\hline 12 & {$\left[{ }^{68} \mathrm{Ga}\right] \mathrm{Ga}-\mathrm{NOTA}-\mathrm{PEG}_{4}-\mathrm{E}[\mathrm{c}(\mathrm{RGDfK})]_{2}$} & U87MG & [78] & \\
\hline 13 & {$\left[{ }^{18} \mathrm{~F}\right] \mathrm{AlF}-\mathrm{NOTA}-\mathrm{PEG}_{4}-\mathrm{E}[\mathrm{c}(\mathrm{RGDfK})]_{2}$} & U87MG & {$[46]$} & \\
\hline 14 & $\begin{array}{c}{\left[{ }^{18} \mathrm{~F}\right] \text { AlF-NOTA-E }\left[\mathrm{PEG}_{4} \text {-c }(\text { RGDfK })\right]_{2}} \\
{\left[{ }^{18} \mathrm{~F}\right] \text { Alfatide II }}\end{array}$ & $\begin{array}{l}\text { U87MG, MDA-MB-435 human breast } \\
\text { cancer }\end{array}$ & {$[43,44,46,52-54]$} & \\
\hline 15 & $\begin{array}{c}{\left[{ }^{68} \mathrm{Ga}\right] \mathrm{Ga}-\mathrm{NOTA}-\mathrm{E}\left[\mathrm{PEG}_{4}-\mathrm{c}(\mathrm{RGDfK})\right]_{2}} \\
{\left[{ }^{68} \mathrm{Ga}\right] \mathrm{Ga}-\mathrm{NOTA}-\mathrm{PRGD}_{2}}\end{array}$ & - & {$[51,79]$} & \\
\hline 16 & $\begin{array}{c}{\left[{ }^{18} \mathrm{~F}\right] \mathrm{FP}-\mathrm{PEG}_{4}-\mathrm{E}\left[\mathrm{PEG}_{4}-\mathrm{c}(\mathrm{RGDfK})\right]_{2}} \\
{\left[{ }^{18} \mathrm{~F}\right] \mathrm{FP}-\mathrm{PPRGD}} \\
\end{array}$ & U87MG, MDA-MB-435 & [45] & \\
\hline 17 & {$\left[{ }^{18} \mathrm{~F}\right] \mathrm{FP}-\mathrm{PEG} \mathrm{2}_{2}-\beta-\mathrm{E}[\mathrm{c}(\mathrm{RGDyK})]_{2}$} & A549, PC-3 & {$[47]$} & Figure 5 \\
\hline 18 & {$\left[{ }^{18} \mathrm{~F}\right] \mathrm{FP}-\mathrm{SAA}-\mathrm{E}\left[\mathrm{c}(\mathrm{RGDyK})_{2}\right.$} & \multirow{2}{*}{ U87MG } & \multirow{2}{*}[48]{} & \multirow{2}{*}{ Figure 6} \\
\hline 19 & {$\left[{ }^{18} \mathrm{~F}\right]$ FB-SAA-E $\left[\mathrm{c}(\mathrm{RGDyK})_{2}\right.$} & & & \\
\hline 20 & NOTA-E[c(RGDyK) $]_{2}$ & \multirow[b]{3}{*}{-} & \multirow[b]{3}{*}{ [49] } & \multirow[b]{3}{*}{ Figure 7} \\
\hline 21 & {$\left[{ }^{68} \mathrm{Ga}\right] \mathrm{Ga}-\mathrm{NOTA}-\mathrm{E}[\mathrm{c}(\mathrm{RGDyK})]_{2}$} & & & \\
\hline 22 & $\begin{array}{l}\left.\left.{ }^{68} \mathrm{Ga}\right] \mathrm{Ga}-N O T A-Y-c(R G D y K)\right] \\
(\mathrm{Y}=2-(4-\text { anilinyl-methyl)-4-(3- } \\
\text { oxopropyl)thiazol-5(4H)-one) }\end{array}$ & & & \\
\hline 23 & {$\left[{ }^{64} \mathrm{Cu}\right] \mathrm{Cu}-\mathrm{DOTA}-\mathrm{E}[\mathrm{c}(\mathrm{RGDfK})]_{2}$} & U87MG, MDA-MB-435 & {$[55,56]$} & \multirow{6}{*}{ Figure 8} \\
\hline 24 & {$\left[{ }^{68} \mathrm{Ga}\right] \mathrm{Ga}-\mathrm{DOTA}-\mathrm{E}[\mathrm{c}(\mathrm{RGDfK})]_{2}$} & $\begin{array}{l}\text { B16-F10-luc melanoma tumors, SK-RC-52, } \\
\text { FaDu }\end{array}$ & {$[61,70]$} & \\
\hline 25 & {$\left[{ }^{64} \mathrm{Cu}\right] \mathrm{Cu}-\mathrm{DOTA}-\mathrm{E}[\mathrm{c}(\mathrm{RGDyK})]_{2}$} & MDA-MB-435 & {$[55]$} & \\
\hline 26 & {$\left[{ }^{64} \mathrm{Cu}\right] \mathrm{Cu}-\mathrm{DOTA}-\mathrm{E}\left\{\mathrm{E}[\mathrm{c}(\mathrm{RGDfK})]_{2}\right\}_{2}$} & U87MG & {$[56,58]$} & \\
\hline 27 & {$\left[{ }^{64} \mathrm{Cu}\right] \mathrm{Cu}-\mathrm{DOTA}-\mathrm{E}\left\{\mathrm{E}[\mathrm{c}(\mathrm{RGDyK})]_{2}\right\}_{2}$} & U87MG, c-neu onco-mice & {$[30]$} & \\
\hline 28 & {$\left[{ }^{64} \mathrm{Cu}\right] \mathrm{Cu}-\mathrm{DOTA}-\mathrm{E}\left(\mathrm{E}\left\{\mathrm{E}[\mathrm{c}(\mathrm{RGDfK})]_{2}\right\}_{2}\right)_{2}$} & U87MG, c-neu onco-mice & {$[30]$} & \\
\hline 29 & $\begin{array}{c}{\left[{ }^{64} \mathrm{Cu}\right] \mathrm{Cu}-\mathrm{NOTA}-\mathrm{PEG}_{4}-\mathrm{E}\left[\left(\mathrm{PEG}_{2}-\mathrm{Tz}-\right.\right.} \\
\mathrm{c}(\mathrm{RGDfK})]_{2}\end{array}$ & \multirow[t]{2}{*}{$\begin{array}{l}\text { HUVEC human umbilical vein } \\
\text { endothelial cells }\end{array}$} & \multirow[t]{2}{*}{ [57] } & \multirow{4}{*}{ Figure 9} \\
\hline 30 & FITC-PEG ${ }_{4}-\mathrm{E}\left[\mathrm{PEG}_{2}-\mathrm{Tz}-\mathrm{c}(\mathrm{RGDfK})\right]_{2}$ & & & \\
\hline 31 & $\begin{array}{c}\left.{ }^{64} \mathrm{Cu}\right] \mathrm{Cu}-\mathrm{DOTA}-\mathrm{PEG}_{4}-\mathrm{E}\left[\mathrm{PEG}_{4}{ }^{-}\right. \\
\mathrm{c}(\mathrm{RGDfK})]_{2}\end{array}$ & \multirow[t]{2}{*}{ U87MG } & \multirow[t]{2}{*}[58]{} & \\
\hline 32 & {$\left[{ }^{64} \mathrm{Cu}\right] \mathrm{Cu}-\mathrm{DOTA}-\mathrm{G}_{3}-\mathrm{E}\left[\mathrm{G}_{3}-\mathrm{c}(\mathrm{RGDfK})\right]_{2}$} & & & \\
\hline 33 & {$\left[{ }^{64} \mathrm{Cu}\right] \mathrm{Cu}-\mathrm{AmBaSar}-\mathrm{E}[\mathrm{c}(\mathrm{RGDyK})]_{2}$} & \multirow{2}{*}{ U87MG } & \multirow{2}{*}[59,60]{} & \multirow{2}{*}{ Figure 10} \\
\hline 34 & {$\left[{ }^{64} \mathrm{Cu}\right] \mathrm{Cu}-\mathrm{AmBaBaSar}-\mathrm{c}(\mathrm{RGDyK})_{2}$} & & & \\
\hline 35 & {$\left[{ }^{68} \mathrm{Ga}\right] \mathrm{Ga}-\mathrm{NOTA}-\mathrm{E}\left[\mathrm{PEG}_{4}-\mathrm{c}(\mathrm{RGDfK})\right]_{2}$} & U87MG: MDA-MB-435 & {$[62]$} & \multirow{5}{*}{ Figure 11} \\
\hline 36 & {$\left[{ }^{68} \mathrm{Ga}\right] \mathrm{Ga}-\mathrm{NOTA}-\mathrm{E}\left[\mathrm{G}_{3}-\mathrm{c}(\mathrm{RGDfK})\right]_{2}$} & $\begin{array}{l}\text { U87MG, MDA-MB-435, HT1080 } \\
\text { fibrosarcoma }\end{array}$ & {$[62,64]$} & \\
\hline 37 & {$\left[{ }^{68} \mathrm{Ga}\right] \mathrm{Ga}-\mathrm{NOTA}-\mathrm{E}\left[\mathrm{G}_{3}-\mathrm{c}(\mathrm{CNGRC})\right]_{2}$} & HT1080 fibrosarcoma & {$[64]$} & \\
\hline 38 & {$\left[{ }^{68} \mathrm{Ga}\right] \mathrm{Ga}-\mathrm{NOTA}-\mathrm{E}[\mathrm{c}(\mathrm{RGDyK})]_{2}$} & \multirow{2}{*}{ U87MG } & \multirow{2}{*}[66]{} & \\
\hline 39 & {$\left[{ }^{68} \mathrm{Ga}\right] \mathrm{Ga}-N O T A-E\left\{E[c(R G D y K)]_{2}\right\}_{2}$} & & & \\
\hline
\end{tabular}


Table 2. Cont.

\begin{tabular}{|c|c|c|c|c|}
\hline$\#$ & Name & Cell \& Tumor Model & Ref. & Figure \\
\hline 40 & {$\left[{ }^{68} \mathrm{Ga}\right] \mathrm{Ga}-N O D A G A-E[c(R G D y K)]_{2}$} & \multirow{2}{*}{ U87MG, H727 human neuroendocrine } & \multirow{2}{*}{ [67] } & \\
\hline 41 & {$\left[{ }^{64} \mathrm{Cu}\right] \mathrm{Cu}-\mathrm{NODAGA}-\mathrm{E}[\mathrm{c}(\mathrm{RGDyK})]_{2}$} & & & \\
\hline 42 & {$\left[{ }^{68} \mathrm{Ga}\right] \mathrm{Ga}-\mathrm{FSC}-[\mathrm{E}-\mathrm{c}(\mathrm{RGDfK})]_{3}$} & $\begin{array}{l}\text { M21 human melanoma, SK-RC-52 } \\
\text { (human renal cell carcinoma), FaDu } \\
\text { (human squamous cell carcinoma) }\end{array}$ & {$[68,70]$} & \multirow{4}{*}{ Figure 12} \\
\hline 43 & {$\left[{ }^{68} \mathrm{Ga}\right] \mathrm{Ga}-\mathrm{FSC}-\left(\mathrm{CH}_{2}\right)-\mathrm{Tz}-\mathrm{c}(\mathrm{RGDfK})$} & \multirow{3}{*}{ U87MG, M21 human melanoma } & \multirow{3}{*}{ [23] } & \\
\hline 44 & {$\left[{ }^{68} \mathrm{Ga}\right] \mathrm{Ga}-\mathrm{FSC}-\left[\left(\mathrm{CH}_{2}\right)-\mathrm{Tz}-\mathrm{c}(\mathrm{RGDfK})\right]_{2}$} & & & \\
\hline 45 & {$\left[{ }^{68} \mathrm{Ga}\right] \mathrm{Ga}-\mathrm{FSC}-\left[\left(\mathrm{CH}_{2}\right)-\mathrm{Tz}-\mathrm{c}(\mathrm{RGDfK})\right]_{3}$} & & & \\
\hline 46 & {$\left[{ }^{68} \mathrm{Ga}\right] \mathrm{Ga}-\mathrm{TRAP}-\mathrm{PEG}_{4}-\mathrm{c}(\mathrm{RGDfK})_{3}$} & $\begin{array}{l}\text { M21 human melanoma, } \\
\text { SK-RC-52, FaDu }\end{array}$ & {$[69,70]$} & \multirow[t]{2}{*}{ Figure 13} \\
\hline 47 & {$\left[{ }^{68} \mathrm{Ga}\right] \mathrm{Ga}-\mathrm{THP}-\mathrm{c}(\mathrm{RGDfK})_{3}$} & SK-RC-52, FaDu & {$[70]$} & \\
\hline
\end{tabular}

Finally, regarding the advantages of multimeric c(RGD) analogs in clinical studies, according to the limited data generated so far, the dimeric structures seem to have an advantage over their monomeric analogs. Even so, additional evaluation is needed with large cohorts of patients in order to determine if the multimeric strategy provides higher sensitivity and specificity for tumor detection and staging over the monomeric RGD compounds and the golden standard $\left[{ }^{18} \mathrm{~F}\right] \mathrm{FDG}$.

\section{Concluding Remarks}

This article describes multimeric c(RGD) ligands targeting integrin $\alpha_{\mathrm{v}} \beta_{3}$ receptors for PET molecular imaging of tumors. Multimerization is generally advantageous and multimeric c(RGD) radioligands have increased binding avidity against $\alpha_{\mathrm{v}} \beta_{3}$ receptors and are more effective in tumor targeting compared to monomeric $\mathrm{c}(\mathrm{RDG})$ radioligands. However, when the number of $c(R G D)$ pharmacophores was increased above 2, it did not enhance the pharmacokinetic properties of the ligand in vivo, despite the benefits of multimerization observed in vitro. The length and flexibility of the linker connecting the $c(R G D)$ pharmacophores and the linker connecting the multimerization scaffold with the chelator group have a significant role in the biological activity of the multimeric c(RGD) ligands. Clinical studies are expected to bring forward valuable information regarding the application benefits of multimeric c(RGD) ligands.

Author Contributions: Conceptualization, C.L. and P.B.; writing-original draft preparation, C.L. and C.S.; writing-review and editing, C.L., C.S., A.K. and A.D.-S.; supervision, P.B.; funding acquisition, P.B. All authors have read and agreed to the published version of the manuscript.

Funding: This research received no external funding.

Conflicts of Interest: The authors declare no conflict of interest.

\section{References}

1. Handl, H.L.; Vagner, J.; Han, H.; Mash, E.; Hruby, V.J.; Gillies, R.J. Hitting multiple targets with multimeric ligands. Expert Opin. Ther. Targets. 2004, 8, 565-586. [CrossRef] [PubMed]

2. Crothers, D.M.; Metzger, H. The influence of polyvalency on the binding properties of antibodies. Immunochemistry 1972, 9 , 341-357. [CrossRef]

3. Yim, C.-B.; Van Der Wildt, B.; Dijkgraaf, I.; Joosten, L.; Eek, A.; Versluis, C.; Rijkers, D.T.S.; Boerman, O.C.; Liskamp, R.M.J. Spacer Effects on in vivo Properties of DOTA-Conjugated Dimeric [Tyr3] Octreotate Peptides Synthesized by a "CuI-Click" and "Sulfo-Click" Ligation Method. ChemBioChem 2011, 12, 750-760. [CrossRef] [PubMed]

4. Baranski, A.-C.; Schäfer, M.; Bauder-Wüst, U.; Wacker, A.; Schmidt, J.; Liolios, C.; Mier, W.; Haberkorn, U.; Eisenhut, M.; Kopka, K.; et al. Improving the Imaging Contrast of ${ }^{68}$ Ga-PSMA-11 by Targeted Linker Design: Charged Spacer Moieties Enhance the Pharmacokinetic Properties. Bioconjugate Chem. 2017, 28, 2485-2492. [CrossRef] [PubMed] 
5. Liolios, C.C.; Fragogeorgi, E.A.; Zikos, C.; Loudos, G.; Xanthopoulos, S.; Bouziotis, P.; Paravatou-Petsotas, M.; Livaniou, E.; Varvarigou, A.D.; Sivolapenko, G.B. Structural modifications of ${ }^{99 \mathrm{~m}} \mathrm{Tc}$-labelled bombesin-like peptides for optimizing pharmacokinetics in prostate tumor targeting. Int. J. Pharm. 2012, 430, 1-17. [CrossRef]

6. Kubas, H.; Schäfer, M.; Bauder-Wüst, U.; Eder, M.; Oltmanns, D.; Haberkorn, U.; Mier, W.; Eisenhut, M. Multivalent cyclic RGD ligands: Influence of linker lengths on receptor binding. Nucl. Med. Biol. 2010, 37, 885-891. [CrossRef]

7. Maresca, K.P.; Hillier, S.M.; Femia, F.J.; Keith, D.; Barone, C.; Joyal, J.L.; Zimmerman, C.N.; Kozikowski, A.P.; Barrett, J.A.; Eckelman, W.C.; et al. A Series of Halogenated Heterodimeric Inhibitors of Prostate Specific Membrane Antigen (PSMA) as Radiolabeled Probes for Targeting Prostate Cancer. J. Med. Chem. 2009, 52, 347-357. [CrossRef]

8. Liolios, C.; Buchmuller, B.; Bauder-Wüst, U.; Schäfer, M.; Leotta, K.; Haberkorn, U.; Eder, M.; Kopka, K.; Buchmuler, B.; Schaefer, M. Monomeric and Dimeric ${ }^{68}$ Ga-Labeled Bombesin Analogues for Positron Emission Tomography (PET) Imaging of Tumors Expressing Gastrin-Releasing Peptide Receptors (GRPrs). J. Med. Chem. 2018, 61, 2062-2074. [CrossRef]

9. Liolios, C.; Shegani, A.; Roupa, I.; Kiritsis, C.; Makarem, A.; Paravatou-Petsotas, M.; Pelecanou, M.; Bouziotis, P.; Papadopoulos, M.; Kopka, K.; et al. Synthesis, characterization and evaluation of ${ }^{68} \mathrm{Ga}$ labelled monomeric and dimeric quinazoline derivatives of the HBED-CC chelator targeting the epidermal growth factor receptor. Bioorganic Chem. 2020, 100, 103855. [CrossRef]

10. Tonini, T.; Rossi, F.; Claudio, P.P. Molecular basis of angiogenesis and cancer. Oncogene 2003, 22, 6549-6556. [CrossRef]

11. Cai, W.; Rao, J.; Gambhir, S.S.; Chen, X. How molecular imaging is speeding up antiangiogenic drug development. Mol. Cancer Ther. 2006, 5, 2624-2633. [CrossRef] [PubMed]

12. Hanahan, D.; Weinberg, R.A. Hallmarks of Cancer: The Next Generation. Cell 2011, 144, 646-674. [CrossRef]

13. Chen, K.; Conti, P.S. Target-specific delivery of peptide-based probes for PET imaging. Adv. Drug Deliv. Rev. 2010, 62, 1005-1022. [CrossRef] [PubMed]

14. Shinderman-Maman, E.; Cohen, K.J.; Weingarten, C.; Nabriski, D.; Twito, O.; Baraf, L.; Hercbergs, A.; Davis, P.J.; Werner, H.; Ellis, M.J.; et al. The thyroid hormone- $\alpha_{\mathrm{V}} \beta_{3}$ integrin axis in ovarian cancer: Regulation of gene transcription and MAPKdependent proliferation. Oncogene 2016, 35, 1977-1987. [CrossRef]

15. Meyer, A.; Van Golen, C.M.; Kim, B.; Van Golen, K.L.; Feldman, E.L. Integrin Expression Regulates Neuroblastoma Attachment and Migration. Neoplasia 2004, 6, 332-342. [CrossRef] [PubMed]

16. Axelsson, R.; Bach-Gansmo, T.; Castell-Conesa, J.; McParland, B.J. An open-label, multicenter, phase 2a study to assess the feasibility of imaging metastases in late-stage cancer patients with the $\alpha_{\mathrm{v}} \beta_{3}$-selective angiogenesis imaging agent ${ }^{99 \mathrm{~m}} \mathrm{Tc}-\mathrm{NC} 100692$. Acta Radiol. 2010, 51, 40-46. [CrossRef] [PubMed]

17. Liu, L.; Song, Y.; Gao, S.; Ji, T.; Zhang, H.; Ji, B.; Chen, B.; Jia, B.; Wang, F.; Xu, Z.; et al. ${ }^{99 m}$ Tc-3PRGD 2 scintimammography in palpable and nonpalpable breast lesions. Mol. Imaging 2014, 13. [CrossRef]

18. Chen, X.; Park, R.; Tohme, M.; Shahinian, A.H.; Bading, J.R.; Conti, P.S. MicroPET and Autoradiographic Imaging of Breast Cancer $\alpha v$-Integrin Expression Using ${ }^{18} \mathrm{~F}$ - and ${ }^{64} \mathrm{Cu}$-Labeled RGD Peptide. Bioconjugate Chem. 2004, 15, 41-49. [CrossRef]

19. Huang, R.; Rofstad, E.K. Integrins as therapeutic targets in the organ-specific metastasis of human malignant melanoma. J. Exp. Clin. Cancer Res. 2018, 37, 1-14. [CrossRef]

20. Liu, S. Radiolabeled Cyclic RGD Peptides as Integrin $\alpha v \beta 3$-Targeted Radiotracers: Maximizing Binding Affinity via Bivalency. Bioconjugate Chem. 2009, 20, 2199-2213. [CrossRef]

21. Shi, J.; Wang, F.; Liu, S. Radiolabeled cyclic RGD peptides as radiotracers for tumor imaging. Biophys. Rep. 2016, 2, 1-20. [CrossRef]

22. Poethko, T.; Schottelius, M.; Thumshirn, G.; Hersel, U.; Herz, M.; Henriksen, G.; Kessler, H.; Schwaiger, M.; Wester, H.J. Two-step methodology for high-yield routine radiohalogenation of peptides: ${ }^{18}$ F-labeled RGD and octreotide analogs. J. Nucl. Med. 2004, $45,892-902$.

23. Kaeopookum, P.; Petrik, M.; Summer, D.; Klinger, M.; Zhai, C.; Rangger, C.; Haubner, R.; Haas, H.; Hajduch, M.; Decristoforo, C. Comparison of ${ }^{68}$ Ga-labeled RGD mono- and multimers based on a clickable siderophore-based scaffold. Nucl. Med. Biol. 2019, 78-79, 1-10. [CrossRef]

24. Chen, H.; Niu, G.; Wu, H.; Chen, X. Clinical Application of Radiolabeled RGD Peptides for PET Imaging of Integrin $\alpha$ v $\beta 3$. Theranostics 2016, 6, 78-92. [CrossRef] [PubMed]

25. Höltke, C.; Faust, A. Molecular imaging of integrins in oncology. Rep. Med. Imaging 2017, 10, 17-30. [CrossRef]

26. Fani, M.; Maecke, H.R.; Okarvi, S.M. Radiolabeled Peptides: Valuable Tools for the Detection and Treatment of Cancer. Theranostics 2012, 2, 481-501. [CrossRef] [PubMed]

27. Rokugawa, T.; Konishi, H.; Ito, M.; Iimori, H.; Nagai, R.; Shimosegawa, E.; Hatazawa, J.; Abe, K. Evaluation of hepatic integrin $\alpha \mathrm{v} \beta 3$ expression in non-alcoholic steatohepatitis (NASH) model mouse by ${ }^{18} \mathrm{~F}_{\mathrm{FPP}-\mathrm{RGD}_{2}}$ PET. EJNMMI Res. $2018,8,40$. [CrossRef]

28. Lucie, S.; Elisabeth, G.; Stéphanie, F.; Guy, S.; Amandine, H.; Corinne, A.R.; Didier, B.; Catherine, S.; Alexeï, G.; Pascal, D.; et al Clustering and Internalization of Integrin $\alpha_{\mathrm{v}} \beta_{3}$ With a Tetrameric RGD-synthetic. Peptide. Mol. Ther. 2009, 17, 837-843. [CrossRef]

29. Dijkgraaf, I.; Kruijtzer, J.A.W.; Liu, S.; Soede, A.C.; Oyen, W.J.G.; Corstens, F.H.M.; Liskamp, R.M.J.; Boerman, O.C. Improved targeting of the $\alpha v \beta 3$ integrin by multimerisation of RGD peptides. Eur. J. Nucl. Med. Mol. Imaging 2007, 34, 267-273. [CrossRef]

30. Li, Z.-B.; Cai, W.; Cao, Q.; Chen, K.; Wu, Z.; Elhendy, A.; Chen, X. ${ }^{64}$ Cu-Labeled Tetrameric and Octameric RGD Peptides for Small-Animal PET of Tumor v 3 Integrin Expression. J. Nucl. Med. 2007, 48, 1162-1171. [CrossRef] [PubMed] 
31. Ermert, J.; Benešová, M.; Hugenberg, V.; Gupta, V.; Spahn, I.; Pietzsch, H.-J.; Liolios, C.; Kopka, K. Radiopharmaceutical Sciences. In Clinical Nuclear Medicine; Springer International Publishing: Cham, Switzerland, 2020; pp. 49-191.

32. Pascali, G.; Matesic, L.; Collier, T.L.; Wyatt, N.; Fraser, B.H.; Pham, T.Q.; Salvadori, P.A.; Greguric, I. Optimization of nucleophilic ${ }^{18}$ F radiofluorinations using a microfluidic reaction approach. Nat. Protoc. 2014, 9, 2017-2029. [CrossRef]

33. Poethko, T.; Schottelius, M.; Thumshirn, G.; Herz, M.; Haubner, R.; Henriksen, G.; Kessler, H.; Schwaiger, M.; Wester, H.-J. Chemoselective pre-conjugate radiohalogenation of unprotected mono- and multimeric peptides via oxime formation. Radiochim. Acta 2004, 92, 317-327. [CrossRef]

34. Chen, X.; Tohme, M.; Park, R.; Hou, Y.; Bading, J.R.; Conti, P.S. Micro-PET Imaging of $\alpha_{\mathrm{v}} \beta_{3}$-Integrin Expression with ${ }^{18}$ F-Labeled Dimeric RGD Peptide. Mol. Imaging 2004, 3, 96-104. [CrossRef] [PubMed]

35. Liu, S.; Liu, H.; Jiang, H.; Xu, Y.; Zhang, H.; Cheng, Z. One-step radiosynthesis of ${ }^{18} \mathrm{~F}-\mathrm{AlF}-\mathrm{NOTA}-\mathrm{RGD}_{2}$ for tumor angiogenesis PET imaging. Eur. J. Nucl. Med. Mol. Imaging 2011, 38, 1732-1741. [CrossRef] [PubMed]

36. Wu, Z.; Li, Z.-B.; Cai, W.; He, L.; Chin, F.T.; Li, F.; Chen, X. ${ }^{18}$ F-labeled mini-PEG spacered RGD dimer $\left({ }^{18}\right.$ F-FPRGD $\left._{2}\right):$ Synthesis and microPET imaging of $\alpha_{v} \beta_{3}$ integrin expression. Eur. J. Nucl. Med. Mol. Imaging 2007, 34, 1823-1831. [CrossRef] [PubMed]

37. Chang, E.; Liu, S.; Gowrishankar, G.; Yaghoubi, S.; Wedgeworth, J.P.; Chin, F.; Berndorff, D.; Gekeler, V.; Gambhir, S.S.; Cheng, Z. Reproducibility study of $\left[{ }^{18} \mathrm{~F}\right] \mathrm{FPP}(\mathrm{RGD})_{2}$ uptake in murine models of human tumor xenografts. Eur. J. Nucl. Med. Mol. Imaging 2010, 38, 722-730. [CrossRef] [PubMed]

38. Lang, L.; Li, W.; Guo, N.; Ma, Y.; Zhu, L.; Kiesewetter, D.O.; Shen, B.; Niu, G.; Chen, X. Comparison Study of [ ${ }^{18}$ F]FAl-NOTAPRGD2, $\left[{ }^{18} \mathrm{~F}\right] \mathrm{FPPRGD}$, and $\left[{ }^{68} \mathrm{Ga}\right] \mathrm{Ga}-\mathrm{NOTA}-\mathrm{PRGD}_{2}$ for PET Imaging of U87MG Tumors in Mice. Bioconjugate Chem. 2011, 22, 2415-2422. [CrossRef]

39. Guo, N.; Lang, L.; Li, W.; Kiesewetter, D.O.; Gao, H.; Niu, G.; Xie, Q.; Chen, X. Quantitative Analysis and Comparison Study of $\left[{ }^{18} \mathrm{~F}\right]$ AlF-NOTA-PRGD $2,\left[{ }^{18} \mathrm{~F}\right] \mathrm{FPPRGD}_{2}$ and $\left[{ }^{68} \mathrm{Ga}\right] \mathrm{Ga}-\mathrm{NOTA}-\mathrm{PRGD}_{2}$ Using a Reference Tissue Model. PLoS ONE 2012, 7, e037506. [CrossRef]

40. Liu, J.; Wang, D.; Meng, X.; Sun, X.; Yuan, S.; Yu, J. 18F-alfatide positron emission tomography may predict anti-angiogenic responses. Oncol. Rep. 2018, 40, 2896-2905. [CrossRef]

41. Wei, Y.-C.; Gao, Y.; Zhang, J.; Fu, Z.; Zheng, J.; Liu, N.; Hu, X.; Hou, W.; Yu, J.; Yuan, S. Stereotactic Comparison Study of ${ }^{18}$ F-Alfatide and ${ }^{18}$ F-FDG PET Imaging in an LLC Tumor-Bearing C57BL/6 Mouse Model. Sci. Rep. 2016, 6, 28757. [CrossRef] [PubMed]

42. Guo, J.; Guo, N.; Lang, L.; Kiesewetter, D.O.; Xie, Q.; Li, Q.; Eden, H.S.; Niu, G.; Chen, X. 18F-Alfatide II and ${ }^{18}$ F-FDG Dual Tracer Dynamic PET for Parametric, Early Prediction of Tumor Response to Therapy. J. Nucl. Med. 2013, 55, 154-160. [CrossRef]

43. Bao, X.; Wang, M.-W.; Luo, J.-M.; Wang, S.-Y.; Zhang, Y.-P.; Zhang, Y.-J. Optimization of Early Response Monitoring and Prediction of Cancer Antiangiogenesis Therapy via Noninvasive PET Molecular Imaging Strategies of Multifactorial Bioparameters. Theranostics 2016, 6, 2084-2098. [CrossRef] [PubMed]

44. Wu, C.; Yue, X.; Lang, L.; Kiesewetter, D.O.; Li, F.; Zhu, Z.; Niu, G.; Chen, X. Longitudinal PET Imaging of Muscular Inflammation Using ${ }^{18}$ F-DPA-714 and ${ }^{18}$ F-Alfatide II and Differentiation with Tumors. Theranostics 2014, 4, 546-555. [CrossRef]

45. Liu, Z.; Liu, S.; Wang, F.; Liu, S.; Chen, X. Noninvasive imaging of tumor integrin expression using ${ }^{18}$ F-labeled RGD dimer peptide with PEG4 linkers. Eur. J. Nucl. Med. Mol. Imaging 2009, 36, 1296-1307. [CrossRef]

46. Guo, J.; Lang, L.; Hu, S.; Guo, N.; Zhu, L.; Sun, Z.; Ma, Y.; Kiesewetter, D.O.; Niu, G.; Xie, Q.; et al. Comparison of Three Dimeric ${ }^{18}$ F-AlF-NOTA-RGD Tracers. Mol. Imaging Biol. 2013, 16, 274-283. [CrossRef] [PubMed]

47. Hu, K.; Tang, X.; Tang, G.; Yao, S.; Yao, B.; Wang, H.; Nie, D.; Liang, X.; Tang, C.; He, S. ${ }^{18}$ F-FP-PEG2- $\beta$-Glu-RGD2: A Symmetric Integrin $\alpha \mathrm{v} \beta 3$-Targeting Radiotracer for Tumor PET Imaging. PLoS ONE 2015, 10, e0138675. [CrossRef] [PubMed]

48. Liu, S.; Liu, Z.; Chen, K.; Yan, Y.; Watzlowik, P.; Wester, H.-J.; Chin, F.T.; Chen, X. ${ }^{18}$ F-Labeled Galacto and PEGylated RGD Dimers for PET Imaging of $\alpha \mathrm{v} \beta 3$ Integrin Expression. Mol. Imaging Biol. 2009, 12, 530-538. [CrossRef] [PubMed]

49. Lang, L.; Ma, Y.; Kiesewetter, D.O.; Chen, X. Stability Analysis of Glutamic Acid Linked Peptides Coupled to NOTA through Different Chemical Linkages. Mol. Pharm. 2014, 11, 3867-3874. [CrossRef] [PubMed]

50. Fersing, C.; Bouhlel, A.; Cantelli, C.; Garrigue, P.; Lisowski, V.; Guillet, B. A Comprehensive Review of Non-Covalent Radiofluorination Approaches Using Aluminum $\left[{ }^{18} \mathrm{~F}\right]$ fluoride: Will $\left[{ }^{18} \mathrm{~F}\right] \mathrm{AlF}$ Replace ${ }^{68} \mathrm{Ga}$ for Metal Chelate Labeling? Molecules 2019, 24, 2866. [CrossRef]

51. Kang, F.; Wang, S.; Tian, F.; Zhao, M.; Zhang, M.; Wang, Z.; Li, G.; Liu, C.; Yang, W.; Li, X.; et al. Comparing the Diagnostic Potential of ${ }^{68} \mathrm{Ga}$-Alfatide II and ${ }^{18}$ F-FDG in Differentiating Between Non-Small Cell Lung Cancer and Tuberculosis. J. Nucl. Med. 2015, 57, 672-677. [CrossRef]

52. Wu, J.; Wang, S.; Zhang, X.; Teng, Z.; Wang, J.; Yung, B.C.; Niu, G.; Zhu, H.; Lu, G.; Chen, X. ${ }^{18}$ F-Alfatide II PET/CT for Identification of Breast Cancer: A Preliminary Clinical Study. J. Nucl. Med. 2018, 59, 1809-1816. [CrossRef]

53. Mi, B.; Yu, C.; Pan, D.; Yang, M.; Wan, W.; Niu, G.; Chen, X. Pilot Prospective Evaluation of ${ }^{18}$ F-Alfatide II for Detection of Skeletal Metastases. Theranostics 2015, 5, 1115-1121. [CrossRef] [PubMed]

54. Yu, C.; Pan, D.; Mi, B.; Xu, Y.; Lang, L.; Niu, G.; Yang, M.; Wan, W.; Chen, X. ${ }^{(18)}$ F-Alfatide II PET/CT in healthy human volunteers and patients with brain metastases. Eur. J. Nucl. Med. Mol. Imaging 2015, 42, 2021-2028. [CrossRef]

55. Chen, X.; Liu, S.; Hou, Y.; Tohme, M.; Park, R.; Bading, J.R.; Conti, P.S. MicroPET imaging of breast cancer $\alpha$ v-integrin expression with Cu-labeled dimeric RGD peptides. Mol. Imaging Biol. 2004, 6, 350-359. [CrossRef] [PubMed] 
56. Wu, Y.; Zhang, X.; Xiong, Z.; Cheng, Z.; Fisher, D.R.; Liu, S.; Gambhir, S.S.; Chen, X. microPET imaging of glioma integrin $\alpha_{v} \beta_{3}$ expression using ${ }^{64} \mathrm{Cu}$-labeled tetrameric RGD peptide. J. Nucl. Med. 2005, 46, 1707-1718. [PubMed]

57. Hedhli, J.; Czerwiński, A.; Schuelke, M.; Płoska, A.; Sowinski, P.; La Hood, L.; Mamer, S.B.; Cole, J.A.; Czaplewska, P.; Banach, M.; et al. Synthesis, Chemical Characterization and Multiscale Biological Evaluation of a Dimeric-cRGD Peptide for Targeted Imaging of $\alpha_{\mathrm{V}} \beta_{3}$ Integrin Activity. Sci. Rep. 2017, 7, 3185. [CrossRef] [PubMed]

58. Shi, J.; Kim, Y.-S.; Zhai, S.; Liu, Z.; Chen, X.; Liu, S. Improving Tumor Uptake and Pharmacokinetics of ${ }^{64}$ Cu-Labeled Cyclic RGD Peptide Dimers with $\mathrm{Gly}_{3}$ and $\mathrm{PEG}_{4}$ linkers. Bioconjugate Chem. 2009, 20, 750-759. [CrossRef] [PubMed]

59. Cai, H.; Li, Z.; Huang, C.-W.; Park, R.; Conti, P.S. ${ }^{64} \mathrm{Cu}$ Labeled AmBaSar-RGD 2 for micro-PET Imaging of Integrin $\alpha_{\mathrm{v}} \beta_{3}$ Expression. Curr. Radiopharm. 2011, 4, 68-74. [CrossRef]

60. Liu, S.; Li, Z.; Yap, L.-P.; Huang, C.-W.; Park, R.; Conti, P.S. Efficient Preparation and Biological Evaluation of a Novel Multivalency Bifunctional Chelator for ${ }^{64} \mathrm{Cu}$ Radiopharmaceuticals. Chem. A Eur. J. 2011, 17, 10222-10225. [CrossRef] [PubMed]

61. Siitonen, R.; Peuhu, E.; Autio, A.K.; Liljenbäck, H.; Mattila, E.; Metsälä, O.; Käkelä, M.; Saanijoki, T.; Dijkgraaf, I.; Jalkanen, S.; et al. ${ }^{68}$ Ga-DOTA-E[c(RGDfK) $]_{2}$ PET Imaging of SHARPIN-Regulated Integrin Activity in Mice. J. Nucl. Med. 2019, 60, 1380-1387. [CrossRef]

62. Liu, Z.; Niu, G.; Shi, J.; Liu, S.; Wang, F.; Liu, S.; Chen, X. ${ }^{68}$ Ga-labeled cyclic RGD dimers with Gly 3 and PEG 4 linkers: Promising agents for tumor integrin $\alpha_{\mathrm{v}} \beta_{3}$ PET imaging. Eur. J. Nucl. Med. Mol. Imaging 2009, 36, 947-957. [CrossRef] [PubMed]

63. Liu, Z.; Niu, G.; Wang, F.; Chen, X. ${ }^{68}$ Ga-labeled NOTA-RGD-BBN peptide for dual integrin and GRPR-targeted tumor imaging. Eur. J. Nucl. Med. Mol. Imaging 2009, 36, 1483-1494. [CrossRef] [PubMed]

64. Shao, Y.; Liang, W.; Kang, F.; Yang, W.; Ma, X.; Li, G.; Zong, S.; Chen, K.; Wang, J. A direct comparison of tumor angiogenesis with ${ }^{68}$ Ga-labeled NGR and RGD peptides in HT-1080 tumor xenografts using microPET imaging. AMINO Acids 2014, 46, 2355-2364. [CrossRef] [PubMed]

65. Shao, Y.; Liang, W.; Kang, F.; Yang, W.; Ma, X.; Li, G.; Zong, S.; Chen, K.; Wang, J. ${ }^{68}$ Ga-Labeled Cyclic NGR Peptide for MicroPET Imaging of CD13 Receptor Expression. Molecules 2014, 19, 11600-11612. [CrossRef]

66. Li, Z.-B.; Chen, K.; Chen, X. ${ }^{68}$ Ga-labeled multimeric RGD peptides for microPET imaging of integrin $\alpha_{\mathrm{v}} \beta_{3}$ expression. Eur. J. Nucl. Med. Mol. Imaging 2008, 35, 1100-1108. [CrossRef] [PubMed]

67. Oxboel, J.; Brandt-Larsen, M.; Schjoeth-Eskesen, C.; Myschetzky, R.; El-Ali, H.H.; Madsen, J.; Kjaer, A. Comparison of two new angiogenesis PET tracers ${ }^{68} \mathrm{Ga}-N O D A G A-E[c(R G D y K)]_{2}$ and ${ }^{64} \mathrm{Cu}-N O D A G A-E[c(R G D y K)]_{2}$; in vivo imaging studies in human xenograft tumors. Nucl. Med. Biol. 2014, 41, 259-267. [CrossRef]

68. Knetsch, P.A.; Zhai, C.; Rangger, C.; Blatzer, M.; Haas, H.; Kaeopookum, P.; Haubner, R.; Decristoforo, C. [ ${ }^{68}$ Ga]FSC-(RGD) 3 a trimeric RGD peptide for imaging $\alpha_{\mathrm{v}} \beta_{3}$ integrin expression based on a novel siderophore derived chelating scaffold—synthesis and evaluation. Nucl. Med. Biol. 2015, 42, 115-122. [CrossRef]

69. Notni, J.; Pohle, K.; Wester, H.-J. Be spoilt for choice with radiolabelled RGD peptides: Preclinical evaluation of ${ }^{68}$ Ga-TRAP(RGD) 3 . Nucl. Med. Biol. 2013, 40, 33-41. [CrossRef]

70. Lobeek, D.; Franssen, G.M.; Ma, M.T.; Wester, H.-J.; Decristoforo, C.; Oyen, W.J.G.; Boerman, O.C.; Terry, S.Y.A.; Rijpkema, M. In Vivo Characterization of $4{ }^{68} \mathrm{Ga}$-Labeled Multimeric RGD Peptides to Image $\alpha_{\mathrm{v}} \beta_{3}$ Integrin Expression in 2 Human Tumor Xenograft Mouse Models. J. Nucl. Med. 2018, 59, 1296-1301. [CrossRef] [PubMed]

71. Liu, J.; Yuan, S.; Wang, L.; Sun, X.; Hu, X.; Meng, X.; Yu, J. Diagnostic and Predictive Value of Using RGD PET/CT in Patients with Cancer: A Systematic Review and Meta-Analysis. BioMed Res. Int. 2019, 2019, 1-15. [CrossRef]

72. Mittra, E.S.; Goris, M.L.; Iagaru, A.H.; Kardan, A.; Burton, L.; Berganos, R.; Chang, E.; Liu, S.; Shen, B.; Chin, F.T.; et al. Pilot Pharmacokinetic and Dosimetric Studies of ${ }^{18}$ F-FPPRGD 2 : A PET Radiopharmaceutical Agent for Imaging $\alpha_{\mathrm{v}} \beta_{3}$ Integrin Levels. Radiology 2011, 260, 182-191. [CrossRef] [PubMed]

73. Iagaru, A.; Mosci, C.; Shen, B.; Chin, F.T.; Mittra, E.; Telli, M.L.; Gambhir, S.S. ${ }^{18}$ F-FPPRGD 2 PET/CT: Pilot Phase Evaluation of Breast Cancer Patients. Radiology 2014, 273, 549-559. [CrossRef]

74. Minamimoto, R.; Jamali, M.; Barkhodari, A.; Mosci, C.; Mittra, E.; Shen, B.; Chin, F.; Gambhir, S.S.; Iagaru, A. Biodistribution of the ${ }^{18}$ F-FPPRGD 2 PET radiopharmaceutical in cancer patients: An atlas of SUV measurements. Eur. J. Nucl. Med. Mol. Imaging 2015, 42, 1850-1858. [CrossRef] [PubMed]

75. Minamimoto, R.; Karam, A.; Jamali, M.; Barkhodari, A.; Gambhir, S.S.; Dorigo, O.; Iagaru, A. Pilot prospective evaluation of ${ }^{18}$ F-FPPRGD 2 PET/CT in patients with cervical and ovarian cancer. Eur. J. Nucl. Med. Mol. Imaging 2015, 43, 1047-1055. [CrossRef] [PubMed]

76. Gao, S.; Liu, N.; Li, W.; Zhao, S.; Teng, X.; Fu, Z.; Sun, X.; Zheng, J.; Ma, L.; Lu, H.; et al. A Pilot Study on Imaging of Integrin $\alpha_{\mathrm{V}} \beta_{3}$ With RGD PET/CT in Suspected Lung Cancer Patients. Int. J. Radiat. Oncol. 2014, 90, S648-S649. [CrossRef]

77. Zhou, Y.; Gao, S.; Huang, Y.; Zheng, J.; Dong, Y.; Zhang, B.; Zhao, S.; Lu, H.; Liu, Z.; Yu, J.; et al. A Pilot Study of ${ }^{18}$ F-Alfatide PET/CT Imaging for Detecting Lymph Node Metastases in Patients with Non-Small Cell Lung Cancer. Sci. Rep. 2017, 7, 2877. [CrossRef]

78. Zheng, K.; Liang, N.; Zhang, J.; Lang, L.; Zhang, W.; Li, S.; Zhao, J.; Niu, G.; Li, F.; Zhu, Z.; et al. ${ }^{68}$ Ga-NOTA-PRGD 2 PET/CT for Integrin Imaging in Patients with Lung Cancer. J. Nucl. Med. 2015, 56, 1823-1827. [CrossRef]

79. Kang, F.; Wang, Z.; Li, G.; Wang, S.; Liu, D.; Zhang, M.; Zhao, M.; Yang, W.; Wang, J. Inter-heterogeneity and intra-heterogeneity of $\alpha \mathrm{v} \beta 3$ in non-small cell lung cancer and small cell lung cancer patients as revealed by ${ }^{68} \mathrm{Ga}^{-\mathrm{RGD}_{2}} \mathrm{PET}$ imaging. Eur. J. Nucl. Med. Mol. Imaging 2017, 44, 1520-1528. [CrossRef] 
80. Arbizu, J.; Tejada, S.; Martí-Climent, J.M.; Díez-Valle, R.; Prieto, E.; Quincoces, G.; Vigil, C.; Idoate, M.A.; Zubieta, J.L.; Penuelas, I.; et al. Quantitative volumetric analysis of gliomas with sequential MRI and ${ }^{11} \mathrm{C}$-methionine PET assessment: Patterns of integration in therapy planning. Eur. J. Nucl. Med. Mol. Imaging 2012, 39, 771-781. [CrossRef] [PubMed]

81. Galldiks, N.; Langen, K.-J.; Holy, R.; Pinkawa, M.; Stoffels, G.; Nolte, K.W.; Kaiser, H.J.; Filss, C.P.; Fink, G.R.; Coenen, H.H.; et al. Assessment of Treatment Response in Patients with Glioblastoma Using O-(2-18 F-Fluoroethyl)-L-Tyrosine PET in Comparison to MRI. J. Nucl. Med. 2012, 53, 1048-1057. [CrossRef] [PubMed]

82. Withofs, N.; Martinive, P.; Vanderick, J.; Bletard, N.; Scagnol, I.; Mievis, F.; Giacomelli, F.; Coucke, P.; Delvenne, P.; Cataldo, D.; et al. $\left[{ }^{18} \mathrm{~F}\right] \mathrm{FPRGD} 2$ PET/CT imaging of integrin $\alpha \mathrm{v} \beta 3$ levels in patients with locally advanced rectal carcinoma. Eur. J. Nucl. Med. Mol. Imaging 2015, 43, 654-662. [CrossRef] [PubMed] 